\title{
Rapid Quantification of Soilborne Pathogen Communities in Wheat-Based Long-Term Field Experiments
}

Richard W. Smiley, Emeritus Plant Pathologist, Stephen Machado, Agronomist, and Karl E. L. Rhinhart, Farm Manager, Oregon State University, Columbia Basin Agricultural Research Center, Pendleton 97801; and Catherine L. Reardon, Soil Microbiologist, and Stewart B. Wuest, Soil Scientist, United States Department of Agriculture-Agricultural Research Service, Columbia Plateau Conservation Research Center, Pendleton, OR 97801

\begin{abstract}
Smiley, R. W., Machado, S., Rhinhart, K. E. L., Reardon, C. L., and Wuest, S. B. 2016. Rapid quantification of soilborne pathogen communities in wheat-based long-term field experiments. Plant Dis. 100:1692-1708.

Rainfed experiments operated continuously for up to 84 years in semiarid eastern Oregon are among the oldest agronomic trials in North America. Disease incidence and severity had been quantified visually but quantification of inoculum density had not been attempted. Natural inoculum of 17 fungal and nematode pathogens were quantified for each of 2 years on eight trials using DNA extracts from soil. Crop type, tillage, rotation, soil fertility, year, and their interactions had large effects on the pathogens. Fusarium culmorum and Pratylenchus thornei were more dominant than $F$. pseudograminearum and P. neglectus where spring crops were grown, and the opposite species dominances occurred where winter wheat was the only crop. Bipolaris sorokiniana and Phoma pinodella were restricted to the presence of spring cereals and pulse crops, respectively.

Helgardia spp. occurred in winter wheat-fallow rotations but not in annual winter wheat. Gaeumannomyces graminis var. tritici was more prevalent in cultivated than noncultivated soils and the opposite generally occurred for Rhizoctonia solani AG-8. Densities of Pythium spp. clade F were high but were also influenced by treatments. Significant treatment effects and interactions were more prevalent in two long-standing ( $>50$-year) annually cropped experiments (29\%) than two long-standing 2-year wheatfallow rotations $(14 \%)$. Associations among pathogens occurred mostly in an 84-year-old annual cereals experiment. This survey provided guidance for research on dynamics of root-infecting pathogens of rainfed field crops and identified two pathogens (Drechslera tritici-repentis and $P$. pinodella) not previously identified at the location.
\end{abstract}

Most information on the effects of crop and soil management practices on diseases of wheat (Triticum aestivum L.) and other rainfed field crops have been developed from short-term ( $<5$ years) experiments. Few studies have defined comparative effects of management treatments in long-term (>30 years) experiments, where multiple pathogens are thought to have attained equilibrium within a specific locality and cropping system. Long-term experiments provide valuable insights into agronomic practices for sustainable crop production (Mitchell et al. 1991), and sometimes reveal apparent reversals of disease relationships reported for shorter-term experiments (Yarham 1981).

Three long-term experiments near Pendleton, OR have been operated continuously for 84 years and are among the oldest active long-term agronomic studies in North America (Mitchell et al. 1991; Rasmussen and Smiley 1994). These nonirrigated experiments in a semiarid region $(<400 \mathrm{~mm}$ precipitation annually) have provided unique insights into agricultural sustainability, soil health, and the productivity and economics of crop production (Collins et al. 1992; Duff et al. 1995; Machado 2011; Machado et al. 2007, 2008; Pikul and Allmaras 1986; Rasmussen and Smiley 1996). Findings have included relationships between diseases caused by soilborne plant-pathogenic fungi and effects of long-term management variables on soil chemical, physical, and microbiological parameters. For example, Rhizoctonia root rot was inversely correlated with soil microbial biomass, Fusarium crown rot was inversely correlated with soil $\mathrm{pH}$ and directly correlated with organic carbon $(\mathrm{C})$ and organic nitrogen $(\mathrm{N})$, and disease-decline phenomena were detected for Rhizoctonia root rot and take-all (Lucas et al. 1993; Smiley et al. 1996a).

A survey of diseases in long-term experiments at Pendleton (Smiley et al. 1996a) was based upon assessments of disease symptoms and

Corresponding author: R. Smiley; E-mail: richard.smiley@oregonstate.edu

Accepted for publication 23 March 2016.

http://dx.doi.org/10.1094/PDIS-09-15-1020-RE

(C) 2016 The American Phytopathological Society pathogen signs before quantitative polymerase chain reaction (qPCR) procedures became available and before it became known that rootlesion nematodes (Pratylenchus spp.) are important components of cereal root diseases in semiarid regions of the Pacific Northwest (PNW) (Smiley 2009a; Smiley et al. 2004, 2005a,b). A high-throughput method to quantify DNA simultaneously for most of the soilborne pathogens important to small grain production in the PNW was developed in Australia. The assay produces quantitative data that closely approximate the densities of living pathogens in soil (McKay et al. 2008; OphelKeller et al. 2008). When used in combination with environmental factors, the DNA assay has been successfully applied to the prediction of disease severity for take-all (Bithell et al. 2012) and Rhizoctonia root rot (Poole et al. 2015). The assay is named PreDicta B and is available through the Root Disease Testing Service of the South Australia Research and Development Institute (http://pir.sa.gov.au/research/services/ molecular_diagnostics/predicta_b). This service is being used as a commercial service and for research on soilborne pathogens (Bithell et al. 2012; Evans and McKay 2012; Paulitz et al. 2010; Smiley et al. 2013a,b). The assay included 10 pathogens commonly isolated from small grain fields in the PNW: Bipolaris sorokiniana (Sacc.) Shoemaker (common root rot), Fusarium culmorum (Wm. G. Sm.) Sacc. (crown rot), F. pseudograminearum O'Donnell \& T. Aoki (crown rot), Gaeumannomyces graminis var. tritici J. Walker (take-all), Helgardia herpotrichoides (Fron) Crous \& W. Gams plus H. acuformis (Nirenberg) Crous \& W. Gams (eyespot), Heterodera avenae Wollenweber (cereal cyst nematode), Pratylenchus neglectus (Rensch) Filipjev \& Schuurmans Steckhoven and P. thornei Sher \& Allen (root-lesion nematodes), Pythium Pringsh. spp. (Pythium damping-off and root rot), and Rhizoctonia solani J. G. Kühn AG-8 (Rhizoctonia root rot). Also included in the assay were pathogens not known to occur in the long-term experiments at Pendleton, including Botryosphaeria Ces. \& De Not. species (black rot, frogeye leaf spot, canker, or dead arm of woody plants; and ear rot of wheat and corn), Ditylenchus dipsaci (Kühn) Filipjev (stem nematode), Drechslera tritici-repentis (Died.) Shoemaker (tan spot or yellow leaf spot), G. graminis var. avenae (E. M. Turner) Dennis (take-all of oats and grasses), Phoma koolunga J. A. Davidson, D. Hartley, Priest, S. Kaczm., Herdina, A. McKay \& E. S. Scott (leaf and 
stem chlorotic and necrotic spots of pea and clover), P. pinodella (L. K. Jones) Morgan-Jones \& K. B. Burch (leaf spots, stem lesions and foot rot of pea and clover), Phytophthora medicaginis E. M. Hansen \& D. P. Maxwell (root rot of alfalfa and chickpea), and Pratylenchus teres Khan $\&$ Singh (root-lesion nematode).

Smiley et al. (2013a,b) utilized the PreDicta B service to examine effects of diversified crop rotations on inoculum density (picograms of DNA per gram of soil) of 14 species or groups of pathogens at a low-rainfall (280 $\mathrm{mm}$ annually) site at Moro, OR. The assays revealed that winter wheat had selected for a greater density of the root-lesion nematode $P$. neglectus and spring wheat had selected for a greater density of $P$. thornei (Smiley et al. 2013a). A shift from a dominance of $P$. neglectus to $P$. thornei was then subsequently detected when the cropping system in a commercial field near Pendleton was changed from winter wheat to spring wheat (Smiley et al. 2014a). Likewise, in the crop experiment at Moro, it was noted that winter wheat selected for $F$. pseudograminearum and treatments that included spring barley (Hordeum vulgare L.) contained nearly equal inoculum densities of $F$. culmorum and $F$. pseudograminearum. Inoculum densities also differed significantly among cropping systems for $G$. graminis var. tritici and Pythium spp. but not for $R$. solani AG-8 (Smiley et al. 2013b). Finally, the qPCR assay also revealed a previously unknown presence of Phoma pinodella but only on a treatment where winter pea (Pisum sativum L.) was rotated with winter wheat.

The primary objective of this 2-year survey was to assess inoculum densities of pathogens in five long-term experiments to provide focus for future research on disease complexes and pathogen dynamics in wheat-based cropping systems. Our hypothesis was that cropping systems would have differential influences on inoculum densities of individual pathogens and, thereby, are likely to alter the balances among pathogens that are potential components of disease complexes. Three additional shorter-term (10 to 13 years) experiments were included to expand the value of this research.

\section{Materials and Methods}

The long-term experimental plots are at an agricultural research center located $13 \mathrm{~km}$ northeast of Pendleton, in Umatilla County, OR $\left(45^{\circ} 43.158^{\prime} \mathrm{N}, 119^{\circ} 37.656^{\prime} \mathrm{W}\right)$. The center is composed of collaborating units of Oregon State University's Columbia Basin
Agricultural Research Center and the United States Department of Agriculture-Agricultural Research Service's Columbia Plateau Conservation Research Center.

The climate is temperate, with warm, dry summers $\left(21^{\circ} \mathrm{C}\right)$ and cool, wet winters $\left(1^{\circ} \mathrm{C}\right)$. About $75 \%$ of the $397 \mathrm{~mm}$ of mean annual precipitation (averaged over 84 years) occurs from November to May. Evaporation exceeds precipitation from March through October. Agriculture at the research center lies within an area of transition between land managed as a 2-year rotation of winter wheat (10month growing season) and fallow (14 months), and land planted annually as a 2-year rotation of winter wheat and a pulse crop such as spring pea, lentil (Lens culinaris Medik.), or chickpea (Cicer arietinum L.). The soil is a deep $(>90 \mathrm{~cm})$, well-drained Walla Walla silt loam; a coarse-silty, mixed, superactive, mesic Typic Haploxeroll. The topography is nearly level and the upper $10 \mathrm{~cm}$ of soil on this 70-ha research center has a range of chemical, physical, and biological characteristics which vary depending upon historical treatments. Examples include: soil $\mathrm{pH}=4.4$ to 6.4 (in $0.01 \mathrm{M} \mathrm{CaCl}_{2}$ ), soil organic matter $=1.8$ to $2.7 \%$, organic, $\mathrm{N}$ at 0.7 to $1.4 \mathrm{~g} / \mathrm{kg}$, organic $\mathrm{C}$ at 10 to $18 \mathrm{~g} / \mathrm{kg}$, bulk density $=1.1$ to $1.3 \mathrm{Mg} / \mathrm{m}^{3}$, and microbial biomass $=\mathrm{C}$ at 255 to $1,158 \mathrm{mg} / \mathrm{kg}$ (Collins et al. 1992; Machado 2011; Pikul and Allmaras, 1986; Rasmussen and Collins, 1991; Rasmussen and Rohde 1988, 1989; Rasmussen and Smiley 1994, 1996). One experiment contained a location factor in which identical tillage treatments were located at the research center and at a farm (the Reese site) $32 \mathrm{~km}$ west of the research center $\left(45^{\circ} 43.432^{\prime} \mathrm{N}\right.$, $\left.119^{\circ} 2.911^{\prime} \mathrm{W}\right)$. The soil at the Reese site is a deep $(>100 \mathrm{~cm})$, well-drained Ritzville silt loam (a coarse-silty, mixed, superactive, mesic Calcidic Haploxeroll) and the mean annual precipitation is $290 \mathrm{~mm}$.

Experiments. Key features of eight experiments sampled during this research are shown in Table 1. Soil samples were collected from 109 individual plots or small fields on 13 to 14 March 2013. The same plots plus six others were resampled on 9 to 10 March 2015. Each sample consisted of a composite of 20 soil cores $(2.5 \mathrm{~cm}$ in diameter by $20 \mathrm{~cm}$ deep) from plots of the sizes shown in Table 1. Cores were centered on rows of young winter wheat seedlings or on rows of wheat stubble from a previous wheat crop, in accordance with procedures recommended for analysis of pathogen DNA (Evans and McKay 2012; McKay et al. 2008). Unless stated otherwise, all

Table 1. Primary features of eight long-term experiments at the research center near Pendleton, OR

\begin{tabular}{|c|c|c|c|c|c|c|c|c|c|c|}
\hline \multirow[b]{2}{*}{ Experiment number, name } & \multirow[b]{2}{*}{ Date $^{r}$} & \multirow[b]{2}{*}{ Age (years) } & \multirow[b]{2}{*}{ Syst $^{\mathrm{s}}$} & \multirow[b]{2}{*}{ Crop $^{t}$} & \multirow[b]{2}{*}{ Exp $^{\mathbf{u}}$} & \multirow[b]{2}{*}{ Treatments $^{\mathrm{v}}$} & \multirow[b]{2}{*}{ Reps $^{\mathbf{w}}$} & \multicolumn{3}{|c|}{ Plots sampled } \\
\hline & & & & & & & & $N^{\mathbf{x}}$ & Size (ha) & Cores/ha \\
\hline 1. Fertility management & 1931 & 84 & $\mathrm{CT}$ & $\mathrm{WW} / \mathrm{CuF}$ & SSP & $2 \mathrm{P}, 6 \mathrm{~F}, 2 \mathrm{Y}$ & 2 & 24 & 0.5 & 40 \\
\hline 2. Tillage-fertility & 1940 & 75 & CT & $\mathrm{WW} / \mathrm{CuF}$ & SSP & $3 \mathrm{~T}, 3 \mathrm{~F}, 2 \mathrm{Y}$ & 3 & 27 & 0.2 & 100 \\
\hline 3. Wheat-pea rotation & 1963 & 52 & CT & WW/SP & SSP & $2 \mathrm{C}, 2 \mathrm{~T}, 2 \mathrm{Y}$ & 3 & 12 & 0.3 & 67 \\
\hline \multirow[t]{2}{*}{ 4. Annual cereals ${ }^{\mathrm{y}}$} & 1932 & 84 & $\mathrm{CT}$ & $\mathrm{AW}, \mathrm{AS}$, or $\mathrm{AB}$ & SSP & $2 \mathrm{~T}, 3 \mathrm{C}, 2 \mathrm{Y}$ & 2 & 12 & 1.0 & 20 \\
\hline & 1997 & 18 & NT & $\mathrm{AW}, \mathrm{AS}$, or $\mathrm{AB}$ & SSP & $2 \mathrm{~T}, 3 \mathrm{C}, 2 \mathrm{Y}$ & 2 & 12 & 1.0 & 20 \\
\hline 5. Pasture versus wheat ${ }^{z}$ & 1931 & 84 & NT & PG, or AW & $\mathrm{RCB}$ & $2 \mathrm{C}, 2 \mathrm{Y}$ & 2 & 4 & 0.5 & 40 \\
\hline 6. Three-year rotations & 2004 & 11 & $\mathrm{CT}+\mathrm{NT}$ & WW/SW/ChF & SSP & $2 \mathrm{~T}, 3 \mathrm{P}, 2 \mathrm{Y}$ & 2 & 12 & $1.4-1.7$ & $12-14$ \\
\hline 7. Organic wheat & 2005 & 10 & $\mathrm{CT}$ & $\mathrm{WC} / \mathrm{CuF}, \mathrm{WM} / \mathrm{CuF}$ & SP & $2 \mathrm{~S}, 2 \mathrm{C}$ & 2 & 8 & 0.02 & 1,000 \\
\hline 8. Winter wheat tillage & 2002 & 13 & $\mathrm{CT}+\mathrm{NT}$ & WW/CuF, WW/ChF & $\mathrm{RCB}$ & $2 \mathrm{~L}, 2 \mathrm{~T}, 2 \mathrm{Y}$ & 4 & 16 & $0.2-0.4$ & $50-100$ \\
\hline
\end{tabular}

$\mathrm{r}$ Date of inception.

s Tillage systems were cultivated (CT), not cultivated (no-till; NT), or comparisons of both tillage systems (CT+NT).

${ }^{t}$ Crops and management. Rotation included crops of winter wheat (WW), spring wheat (SW), spring barley (SB), spring pea (SP), spring wheat plus clover (WC), or spring wheat plus medic (WM). Crops grown without rotation included annual winter wheat (AW), annual spring wheat (AS), annual spring barley (AB), or perennial grasses $(\mathrm{PG})$. Some rotations also included cultivated fallow (CuF) or chemical fallow (no-till; $\mathrm{ChF}$ ).

u Experimental designs used for analysis included randomized complete blocks (RCB), split plot (SP), or split-split plot (SSP).

$\checkmark$ Experimental treatments, described in the Methods section, are abbreviated as the number of treatments for crop (C), fertility (F), physical location (L), rotation phase $(\mathrm{P})$, cropping system $(\mathrm{S})$, tillage $(\mathrm{T})$, or year $(\mathrm{Y})$. Treatments are listed in the order in which they were applied for analysis; for example, 2P,6F,2Y indicates that rotation phase was the whole plot, fertility treatment was the subplot, and year was the sub-subplot.

${ }^{w}$ Number of replicates sampled in each experiment.

${ }^{x}$ Number of plots per year.

y Annual cereals were grown in a cultivated block since 1931, with winter wheat grown until the main block was divided into three subblocks during 1982 and then planted to either to WW, SW, or SB on the same subblock every year thereafter. An adjacent main block with the same three crops being produced annually on subblocks without cultivation was initiated in 1997.

${ }^{z}$ Perennial pasture and annual winter wheat blocks were first planted during 1931. The winter wheat block was cultivated between crops until 1998 and was not cultivated thereafter. 
plantings were of 'ORCF 102' winter wheat, 'Louise' spring wheat, 'Champion' spring barley, or 'Banner' spring pea. Primary features of each experiment are shown in Table 1. Additional details are as follows.

Experiment 1: Fertility management. The experimental design was a split plot in a randomized complete block arrangement. A 2-year winter wheat-fallow rotation experiment contained duplicate, offset rotation phases (main plots), which allowed a crop to be harvested each year since 1931. Each main plot consisted of nine fertility treatments (subplots) replicated two times. Repeated sampling during 2 years was treated as the sub-subplot level for analysis.

Historically, this experiment has been known as the 'residue management trial.' Six of the nine treatments were sampled for this research: (i) no added fertilizer since 1931 (0 N), (ii) application of $\mathrm{N}$ at $45 \mathrm{~kg} / \mathrm{ha}$ before each wheat crop $(45 \mathrm{~N}$, ammonium nitrate broadcast from 1967 to 1988 , and urea-ammonium nitrate banded $15 \mathrm{~cm}$ deep with 25 -cm shank spacing from 1989 to present), (iii) application of $\mathrm{N}$ at $90 \mathrm{~kg} / \mathrm{ha}(90 \mathrm{~N})$ before each wheat crop, (iv) treatment iii repeated, except that the wheat stubble was burned in the spring (90 N + burn), (v) application of cow manure $(22.4 \mathrm{Mg} / \mathrm{ha} \mathrm{bi-}$ ennially, averaging $\mathrm{N}$ at $111 \mathrm{~kg} / \mathrm{ha}$ to each crop) several days prior to plowing the wheat stubble (manure), and (vi) pea vines $(2.24 \mathrm{Mg} / \mathrm{ha}$ biennially, averaging $\mathrm{N}$ at $34 \mathrm{~kg} / \mathrm{ha}$ to each crop) applied several days prior to plowing wheat stubble (pea).

All treatments were moldboard plowed in the spring after the residue amendments had been added or the stubble had been burned. Repeated shallow secondary tillage with a rod-weeder was used to conserve moisture and control weeds during fallow. Soil was collected from both replicates of each rotation phase. Half of the samples were taken from soil under stubble remaining from the wheat harvest the previous year, and the other half were from soil where wheat plants had been planted into cultivated fallow 6 months earlier. When sampled during April, the winter wheat was still small due to a neardormant state from November through February.

Experiment 2: Tillage-fertility. The experimental design was a split plot in three randomized complete blocks. A 2-year winter wheat-fallow experiment contained three tillage treatments (main plots) and six $\mathrm{N}$ application rate treatments (subplots). Repeated samplings over 2 years were analyzed as the sub-subplot level.

Historically, this experiment has been known as the 'Ballenger trial.' A crop was harvested during alternate years since 1940 and young winter wheat plants were growing each year when samples were collected for this survey. Tillage treatments included moldboard plow (95\% of crop residue buried), offset disk (60\% of residue buried), and 30-cm subsurface sweeps (35\% of residue buried). Three $\mathrm{N}$ treatments were sampled for this research: applications of $\mathrm{N}$ at 45,90 , or $135 \mathrm{~kg} / \mathrm{ha}$ using urea-ammonium nitrate banded at a 15 -cm depth since 1989 .

Experiment 3: Wheat-pea rotation. The experimental design was a split plot in a randomized complete block arrangement with four replications. A 2-year winter wheat-spring pea rotation contained four replicate blocks of each crop (main plot). There were four tillage treatments randomized within each crop block (subplot). We sampled three replicates of two tillage treatments (conventional and conservation tillage) in both crop phases of the rotation. Repeated samplings over 2 years were analyzed as the sub-subplot level.

Conventional tillage consisted of moldboard plowing in the spring before planting pea and again in autumn before planting wheat. Conservation tillage consisted of no tillage before planting pea and shallow sweep tillage before wheat. Wheat and pea were fertilized with ammonium nitrate ( $\mathrm{N}$ at $90 \mathrm{~kg} / \mathrm{ha}$ ) and ammonium phosphate sulfate ( $\mathrm{N}$ at $23 \mathrm{~kg} / \mathrm{ha}$ ), respectively.

Experiment 4: Annual cereals. The experiment consisted of two main plots (cultivated and noncultivated). Within each main plot were three randomized subplots where winter wheat, spring wheat, or spring barley were grown annually without rotation. Each of the six subplots was sampled in two places to provide replicate samples each of the 2 years. Repeated samplings over 2 years were analyzed as the sub-subplot level.

From 1931 to 1982, the field was planted annually to winter wheat and managed using a conventional tillage system consisting of a moldboard plow followed by disking. In 1982, the plot was divided into three subplots that were planted annually to either winter wheat (84 years), spring wheat (33 years), or spring barley (33 years) on the same subplot each year. Soil in each subplot continued to be cultivated as it was from 1931 to 1982, except that tillage occurred during the autumn in the winter wheat subplot and during the spring in the subplots planted to spring cereals. One sample was collected from each half of each cereal subplot each year, and the experiment was analyzed using the two samples as replicates.

An identical series of the three cereal subplots was established during 1997 on an adjacent field that is not tilled between crops. Prior to 1997, the main plot had been used for a winter wheat-cultivated fallow rotation. Subplots in the noncultivated main plot were sampled as described for the cultivated main plot of annual cereals.

Experiment 5: Pasture versus wheat. The experimental design was a randomized complete block containing two crops (first factor). Repeated samplings over 2 years were analyzed as a second factor.

A perennial grass pasture first planted in 1931 was used to approximate virgin grassland. The pasture received limited grazing by cattle until 1985 and was not grazed after 1985. The pasture was occasionally overseeded with introduced grasses and, at the time of sampling, was dominated by tall fescue (Festuca arundinacea Schreb.) and had lesser amounts of bulbous bluegrass (Poa bulbosa L.) and foxtail (Setaria viridis (L.) Beauv. and S. pumila (Poir.) Roem. \& Schult.). As a comparison with the pasture, we also sampled a nearby block of winter wheat that had been planted each year since 1931. It was cultivated between harvest and planting each year from inception until 1998. After 1998, the block had been managed without tillage (19 years). Two samples collected from separate halves of each of the two plots each year were analyzed as "replicates" within these nonreplicated plots (Table 1 ).

Experiment 6: Three-year rotations. The experimental design was a split plot arranged in randomized complete blocks with two replications. Fields either cultivated by moldboard plow or noncultivated (no-till) were the main plots, in which two replications of each phase of a 3-year rotation (subplots of winter wheat, spring wheat, or fallow) occurred each year (Table 1). Sampling during each of 2 years was analyzed at the sub-subplot level.

Experiment 7: Organic wheat. The experimental design was a five-level factorial experiment that included three replicates of five treatments: (i) two 2-year cropping systems (cover crop or intercrop), (ii) two phases of each cropping system (planted or fallow), (iii) two spring wheat cultivars, (iv) two types of legume mixtures (clover or medic), and (v) four $\mathrm{N}$ application rates ( $\mathrm{N}$ at $0,13,27$, or $31 \mathrm{~kg} / \mathrm{ha} /$ year from an organic 4-4-4 fertilizer), for a total of 192 plots. The cover crop options included spring wheat alternated with a mixture of either nine dryland clover species (Trifolium L. spp.) or six dryland medic species (Medicago L. spp.). The intercrop options included spring wheat planted simultaneously with either the clover or the medic mixture. The cover crop and intercrop systems were each a 2-year rotation with a planted and a fallow phase. Both systems were tilled between crops using a sweep cultivator.

During 2015, we sampled two replicates of each pulse mixture (clover versus medic) in each cropping system (cover crop versus intercrop), sampling from only one wheat cultivar (Louise) and one $\mathrm{N}$-rate treatment ( $\mathrm{N}$ at $31 \mathrm{~kg} / \mathrm{kg} /$ year). Samples were collected following the spring wheat phase of the rotation. Data were analyzed as a split-plot experiment, with cropping system as the main plot and pulse mixture as the subplot. During 2013, we collected preliminary samples from the same plots but combined the pulse crop treatments into a single composite sample which contained a mixture of the clover and medic treatments within each cropping system. The two preliminary samples were not included in the statistical analysis but were used as a comparison with the more comprehensive sampling conducted during 2015.

Experiment 8: Winter wheat tillage. The experiment was a randomized complete block with four replications. Two tillage systems were compared at two locations (first factor): the research center and the Reese site. At both locations, annual winter wheat was managed with either minimum tillage or without tillage from 2002 to 2008 
(second factor). During 2008, the tillage systems were maintained but the crop management at each location was changed to planting 'Bobtail' winter wheat during alternate years. The minimum-tillage fallow was created by a low-disturbance sweep during late spring, which was the only tillage unless rod weeding became necessary to control weeds during the summer. Noncultivated rotations were managed using herbicides to control weeds. Repeated samplings over 2 years were treated as the third factor for analysis.

Pathogen identification and inoculum density. Soil samples were stored at $4{ }^{\circ} \mathrm{C}$ for up to 2 days at field moisture level. They were then dried in an oven at $40^{\circ} \mathrm{C}$ for $48 \mathrm{~h}$ to stabilize the pathogen DNA (McKay et al. 2008). A well-mixed subsample of dried soil (500 g in 2013 and $400 \mathrm{~g}$ in 2015) from each replicate was processed by the Root Disease Testing Service (RDTS), South Australia Research and Development Institute, Adelaide, Australia. The RDTS used a proprietary procedure (PreDicta B; http://pir.sa.gov.au/research/ services/molecular_diagnostics/predicta_b) to extract DNA from the entire sample (Ophel-Keller et al. 2008). DNA was then transferred to an analytical laboratory where robotic pipetting stations prepared subsamples for a series of qPCR assays in 384-well plates (Ophel-Keller et al. 2008). The developers of the assays reported that DNA of fungi and nematodes became mostly undetectable within a week after the organism had died, meaning that results of the assays closely approximated the DNA density in soil for living organisms (Ophel-Keller et al. 2008). Fungal inoculum concentrations in pictograms of DNA per gram of soil was reported during both sampling years for $B$. sorokiniana, $F$. culmorum, $F$. pseudograminearum, G. graminis var. avenae, G. graminis var. tritici, Phoma pinodella, Pythium spp. clade F (LéVesque and De Cock 2004), Phytophthora medicaginis, and $R$. solani AG-8. Separate DNA assays were performed to differentiate between two haplotypes (numbers 1 and 2) of $F$. pseudograminearum that occur in Australia (Bentley et al. 2008). Additionally, during 2015, inoculum densities of Botryosphaeria spp. clade 2, D. tritici-repentis, and Helgardia spp. were reported by RDTS as copies of DNA per g of soil. Inoculum density data for several of these pathogens have been associated with levels of disease risk in Australia and New Zealand (Bithell et al. 2012; McKay et al. 2008; Ophel-Keller et al. 2008; Poole et al. 2015) but no such correlations have been reported in North America. Nematodes were reported as nematodes per gram of soil based on standard curves that correlated DNA concentration with nematode number. Each life stage (egg, juvenile, and adult) yields an approximately equal amount of DNA (Yan et al. 2013). Nematode species reported in each sampling year included Ditylenchus dipsaci, Heterodera avenae, Pratylenchus neglectus, $P$. thornei, and $P$. teres.

Weather. Weather at the research center was monitored by an official U.S. National Weather Service recording station, located within $0.5 \mathrm{~km}$ of the experiments we sampled (http://w2.weather.gov/climate/ xmacis.php?wfo=pdt).

Statistical analyses. Effects of crop management factors and years on individual pathogens within each experiment were analyzed using the designs shown in Table 1; six experiments were split-split plots, one was a split plot, and two were randomized complete blocks. The table indicates the order of treatment effects used for analysis; whole plot or first factor, subplot or second factor, and sub-subplot or third factor. Replicates were treated as blocks. Analyses were performed using the generalized linear model program in CoStat (CoStat Statistical Software v. 6.400; CoHort Software, Monterey, CA). Effects of crop, fertility, location, rotation phase, cropping system, and tillage were treated as fixed effects and year as a random effect. When treatment means were significant at $P<0.05$, means were separated using the Tukey's honestly significant difference test (HSD). Nine pathogens were evaluated during both years in seven experiments. Because only $14 \%$ ( 9 of 63 ) of main treatment effects for year were significant and only 20 of a possible 189 interactions between year and one or more other treatments were significant, data were grouped over years within individual experiments and were reanalyzed without year as a variable. Potential associations between pairs of pathogens were examined by regressing DNA concentrations of all pairs of individual pathogens within individual experiments, using either linear or polynomial regression analyses. Similar regressions of pathogen DNA were evaluated for selected other subsets of whole-plot or subplot treatments, such as data restricted by year, tillage system, crop type, or phase of a rotation. Highly significant Pearson correlation coefficients $\left(R^{2}>0.7\right.$, with an associated $\left.P<0.0001\right)$ were selected for plotting of regressions. These limits were arbitrarily assigned to identify the most important of the many significant correlations in the data set.

\section{Results}

Mean monthly temperatures at a 5-cm depth were nearly equal each year: 0,4 , and $8^{\circ} \mathrm{C}$ in January, February, and March, respectively. Precipitation was variable over the 6-month period prior to sampling during March 2013 and 2015: 168 and 276 mm, respectively, representing 32\% less and $11 \%$ more than the 84 -year mean $(248 \mathrm{~mm})$ for that interval. Although precipitation varied over years, the main effect of year differed significantly $(P<0.05)$ for only 9 of 63 observations (Table 2$)$ in these apparently well-stabilized long-term experiments.

A summary of pathogenic fungi and parasitic nematodes detected in this research is presented in Table 3. With one exception, the table reports 2-year mean minimum and maximum inoculum densities for each pathogen averaged across replicates for individual treatments within each experiment. Data for experiment 7 is from a single year of comprehensive sampling during 2015. Inoculum densities for 6 of the 11 pathogens shown in Table 3 were significantly affected by one or more treatment effects or treatment interactions in at least five of the eight experiments. The pathogens that were frequently influenced by experimental variables included the fungi $F$. culmorum, G. graminis var. tritici, Pythium spp. clade F, and $R$. solani AG-8, and the nematodes $P$. neglectus and $P$. thornei.

During the course of this research, in eight experiments, we evaluated a total of 225 possible main treatment effects (Table 2) for nine pathogens that were present at the experimental location (Table 3). Significant main effects were revealed for $24 \%$ (53 of 225) of possible combinations of main effects and individual pathogens (Table 2). Likewise, we evaluated 270 possible interactions and determined that $16 \%$ (42 of 270) were significant (Table 2). In four older experiments (experiments 1 to 4 ), the significant main effects and interactions were each more prevalent in the two annually cropped experiments (experiments 3 and 4;29\% of possible main effects and interactions) compared with two wheat-fallow rotations (experiments 1 and 2; $14 \%$ ). Significantly positive and negative associations among pathogens were revealed, with most of them occurring in the 84-year-old annual cereals experiment (experiment 4 , as described later).

Maximum inoculum densities of $F$. pseudograminearum were numerically greater than for $F$. culmorum in five experiments (Table 3 ). The haplotype of $F$. pseudograminearum detected in these studies was entirely of the haplotype detected by the PreDicta B "Fusarium Test 1". The dominant species of root-lesion nematode was $P$. neglectus where winter wheat was the only crop grown (Table 3 ). A dominance of $P$. thorne $i$ was favored when spring wheat and pulse crops were grown in experiment 7 (Table 3). Pathogens included in the PreDicta B assay but not detected in this survey were Botryosphaeria spp. clade 2, Phoma koolunga, Phytophthora medicaginis, D. dipsaci, Pratylenchus teres, and $H$. avenae.

Experiment 1: Fertility management. Pathogens for which significant treatment differences were detected included $G$. graminis var. tritici, Phoma pinodella, Pythium spp., and Pratylenchus neglectus (Table 2). The only significant interaction among treatments for the three fungal pathogens was the interaction of rotation phase-fertility treatment for G. graminis var. tritici. That interaction indicated that inoculum concentration did not differ greatly between the planted and fallow phases for the $0 \mathrm{~N}$ and pea vine treatments but did differ greatly between the two rotational phases for each of the other four fertility treatments. In each treatment, a much lower inoculum concentration occurred during the year following fallow compared with the year following wheat. Inoculum density of G. graminis var. tritici was significantly affected by main fertility treatments, with greater DNA densities in the $90 \mathrm{~N}+$ burn treatment than in the $0 \mathrm{~N}$ or $90 \mathrm{~N}$ treatments: $8.8,0.4$, and $0.2 \mathrm{pg} / \mathrm{g}$ of soil, respectively $\left(\mathrm{HSD}_{0.05}=5.3\right)$. The $90 \mathrm{~N}+$ burn treatment following 
wheat had significantly more DNA of G. graminis var. tritici than in the $0 \mathrm{~N}, 90 \mathrm{~N}$, and pea treatments following wheat and in all treatments following the fallow phase (Table 4). Inoculum of Phoma pinodella was also significantly affected by the main effect of treatment (Table 2); this pathogen of pulse crops was detected only in the pea vine treatment of each rotational phase (Table 4).

The density of Pythium spp. was also significantly affected by fertility treatment (Table 2), with 38.9, 25.8, 15.9, 15.6, 12.9, and
$12.5 \mathrm{pg} / \mathrm{g}$ in the manure, pea, $90 \mathrm{~N}, 45 \mathrm{~N}, 0 \mathrm{~N}$, and $90 \mathrm{~N}+$ burn treatments, respectively $\left(\mathrm{HSD}_{0.05}=17.3\right)$. The density of Pythium spp. was especially high in both rotational phases of the manure treatment (Table 4).

The density of Pratylenchus neglectus was influenced by significant fertility treatment-rotation phase and fertility-year interactions (Table 2). The fertility-phase interaction indicated nearly equal densities of $P$. neglectus in the pea treatment of each phase but higher

Table 2. Table of significant $(P>F)$ treatment effects for treatment main effects and for interactions of inoculum densities of pathogens detected in eight experiments at the research center near Pendleton, $\mathrm{OR}^{\mathrm{w}}$

\begin{tabular}{|c|c|c|c|c|c|c|c|}
\hline \multirow{3}{*}{$\frac{\text { Experiment, treatments, pathogens }{ }^{\mathbf{y}}}{\text { 1. Fertility management; } 2 \mathrm{P}, 6 \mathrm{~F}, 2 \mathrm{Y}}$} & \multicolumn{3}{|c|}{ Main effects ${ }^{x}$} & & & & \\
\hline & \multirow{2}{*}{$\begin{array}{c}\text { Whole } \\
\mathrm{P}\end{array}$} & \multirow{2}{*}{$\begin{array}{c}\text { Sub } \\
\mathrm{F}\end{array}$} & \multirow{2}{*}{$\frac{\text { Sub-sub }}{\mathrm{Y}}$} & \multicolumn{4}{|c|}{ Interactions } \\
\hline & & & & $\mathrm{P} \times \mathrm{F}$ & $\mathrm{P} \times \mathrm{Y}$ & $\mathrm{F} \times \mathrm{Y}$ & $\mathrm{P} \times \mathrm{F} \times \mathrm{Y}$ \\
\hline Gaeumannomyces graminis var. tritici & 0.3281 & 0.0365 & 0.5834 & 0.0279 & 0.6937 & 0.7311 & 0.8084 \\
\hline Phoma pinodella & 0.5862 & 0.0130 & 0.8266 & 0.8841 & 0.2712 & 0.9980 & 0.3174 \\
\hline Pythium spp. clade $\mathrm{F}$ & 0.4459 & 0.0416 & 0.4000 & 0.1199 & 0.2499 & 0.5511 & 0.2992 \\
\hline Pratylenchus neglectus & 0.1708 & $<0.0001$ & 0.0007 & 0.0454 & 0.6672 & 0.0500 & 0.6972 \\
\hline 2. Tillage-fertility; $3 \mathrm{~T}, 3 \mathrm{~F}, 2 \mathrm{Y}$ & $\mathrm{T}$ & $\mathrm{F}$ & $\mathrm{Y}$ & $\mathrm{T} \times \mathrm{F}$ & $\mathrm{T} \times \mathrm{Y}$ & $\mathrm{F} \times \mathrm{Y}$ & $\mathrm{T} \times \mathrm{F} \times \mathrm{Y}$ \\
\hline Fusarium culmorum & 0.1443 & 0.0004 & 0.6312 & 0.7473 & 0.2836 & 0.0806 & 0.0116 \\
\hline G. graminis var. tritici & 0.0223 & 0.7833 & 0.4039 & 0.2472 & 0.1655 & 0.2489 & 0.2028 \\
\hline Pythium spp. clade F & 0.0004 & 0.0073 & $<0.0001$ & 0.1457 & 0.0010 & 0.1475 & 0.5601 \\
\hline Pratylenchus neglectus & 0.2325 & 0.0002 & 0.0007 & 0.3276 & 0.1942 & 0.0008 & 0.4907 \\
\hline 3. Wheat-pea rotation; $2 \mathrm{C}, 2 \mathrm{~T}, 2 \mathrm{Y}$ & $\mathrm{C}$ & $\mathrm{T}$ & $\mathrm{Y}$ & $\mathrm{C} \times \mathrm{T}$ & $\mathrm{C} \times \mathrm{Y}$ & $\mathrm{T} \times \mathrm{Y}$ & $\mathrm{C} \times \mathrm{T} \times \mathrm{Y}$ \\
\hline F. culmorum & 0.3757 & 0.2832 & 0.3549 & 0.5408 & 0.6988 & 0.4729 & 0.0390 \\
\hline G. graminis var. tritici & 0.1007 & 0.1940 & 0.1364 & 0.4568 & 0.1364 & 0.0414 & 0.2279 \\
\hline Phoma pinodella & 0.0201 & 0.0054 & 0.0034 & 0.0037 & 0.2583 & 0.2252 & 0.1990 \\
\hline Pythium spp. clade $\mathrm{F}$ & 0.0566 & 0.6715 & 0.2440 & 0.0218 & 0.0061 & 0.0008 & 0.3441 \\
\hline Rhizoctonia solani AG-8 & 0.1388 & 0.0407 & 0.2168 & 0.0492 & 0.1728 & 0.2054 & 0.1635 \\
\hline Pratylenchus neglectus & 0.0065 & 0.0005 & 0.7731 & 0.0018 & 0.7565 & 0.4743 & 0.6757 \\
\hline P. thornei & 0.0049 & 0.0001 & 0.0638 & 0.0106 & 0.3627 & 0.0025 & 0.0823 \\
\hline 4. Annual cereals; $2 \mathrm{~T}, 3 \mathrm{C}, 2 \mathrm{Y}$ & $\mathrm{T}$ & $\mathrm{C}$ & $\mathrm{Y}$ & $\mathrm{T} \times \mathrm{C}$ & $\mathrm{T} \times \mathrm{Y}$ & $\mathrm{C} \times \mathrm{Y}$ & $\mathrm{T} \times \mathrm{C} \times \mathrm{Y}$ \\
\hline Bipolaris sorokiniana & 0.3736 & 0.0026 & 0.9596 & 0.0064 & 0.7683 & 0.1231 & 0.0978 \\
\hline F. culmorum & 0.1830 & 0.0158 & 0.0062 & 0.0023 & 0.0144 & 0.0147 & 0.0083 \\
\hline F. pseudograminearum & 0.0866 & 0.0294 & 0.0626 & 0.0133 & 0.5583 & 0.4145 & 0.1972 \\
\hline G. graminis var. tritici & 0.0035 & 0.0012 & $<0.0001$ & 0.0012 & $<0.0001$ & $<0.0001$ & $<0.0001$ \\
\hline Pythium spp. clade $\mathrm{F}$ & 0.1078 & 0.0021 & 0.3186 & 0.0340 & 0.1013 & 0.2592 & 0.0138 \\
\hline P. neglectus & 0.9324 & 0.0046 & 0.0007 & 0.1347 & 0.0015 & 0.0006 & 0.0012 \\
\hline P. thornei & 0.3432 & 0.0044 & 0.0145 & 0.0040 & 0.0202 & 0.0016 & 0.0116 \\
\hline 5. Pasture versus wheat; $2 \mathrm{C}, 2 \mathrm{Y}^{\mathrm{z}}$ & C & Y & $\ldots$ & $\mathrm{C} \times \mathrm{Y}$ & $\ldots$ & $\ldots$ & $\ldots$ \\
\hline F. culmorum & 0.0491 & 0.9415 & $\ldots$ & 0.9747 & $\ldots$ & $\ldots$ & $\ldots$ \\
\hline G. graminis var. tritici & 0.0503 & 0.0164 & $\ldots$ & 0.0425 & $\ldots$ & $\ldots$ & $\ldots$ \\
\hline R. solani AG-8 & 0.1510 & 0.0386 & $\ldots$ & 0.0753 & $\ldots$ & $\ldots$ & $\ldots$ \\
\hline 6. Three-year rotations; $2 \mathrm{~T}, 3 \mathrm{P}, 2 \mathrm{Y}$ & $\mathrm{T}$ & $\mathrm{P}$ & $\mathrm{Y}$ & $\mathrm{T} \times \mathrm{P}$ & $\mathrm{T} \times \mathrm{Y}$ & $\mathrm{P} \times \mathrm{Y}$ & $\mathrm{T} \times \mathrm{P} \times \mathrm{Y}$ \\
\hline F. pseudograminearum & 0.0775 & 0.0470 & 0.3158 & 0.1921 & 0.7067 & 0.7104 & 0.2643 \\
\hline Helgardia spp. & 0.2054 & 0.0490 & $\ldots$ & 0.0490 & $\ldots$ & $\ldots$ & $\ldots$ \\
\hline R. solani AG-8 & 0.0049 & 0.4805 & 0.2075 & 0.4591 & 0.2826 & 0.4031 & 0.4071 \\
\hline P. neglectus & 0.0101 & 0.0002 & 0.1662 & 0.0031 & 0.5042 & 0.0771 & 0.2041 \\
\hline P. thornei & 0.0458 & 0.0479 & 0.3138 & 0.0104 & 0.1328 & 0.6432 & 0.3697 \\
\hline 7. Organic wheat; $2 \mathrm{~S}, 2 \mathrm{C}$ & $\mathrm{S}$ & $\mathrm{C}$ & $\ldots$ & $\mathrm{S} \times \mathrm{C}$ & $\ldots$ & $\ldots$ & $\ldots$ \\
\hline F. culmorum & 0.2208 & 0.0005 & $\ldots$ & 0.0001 & $\ldots$ & $\ldots$ & $\ldots$ \\
\hline Pythium spp. clade $\mathrm{F}$ & 0.0341 & 0.2414 & $\ldots$ & 0.9070 & $\ldots$ & $\ldots$ & $\ldots$ \\
\hline R. solani AG-8 & 0.0403 & 0.1229 & $\ldots$ & 0.0578 & $\ldots$ & $\ldots$ & $\ldots$ \\
\hline P. thornei & 0.0493 & 0.3015 & $\ldots$ & 0.7330 & $\ldots$ & $\ldots$ & $\ldots$ \\
\hline 8. Winter wheat tillage; $2 \mathrm{~L}, 2 \mathrm{~T}, 2 \mathrm{Y}^{\mathrm{z}}$ & $\mathrm{L}$ & $\mathrm{T}$ & $\mathrm{Y}$ & $\mathrm{L} \times \mathrm{T}$ & $\mathrm{L} \times \mathrm{Y}$ & $\mathrm{T} \times \mathrm{Y}$ & $\mathrm{L} \times \mathrm{T} \times \mathrm{Y}$ \\
\hline F. culmorum & 0.0262 & 0.2435 & 0.8484 & 0.2519 & 0.9521 & 0.5776 & 0.4571 \\
\hline F. pseudograminearum & 0.0025 & 0.0117 & 0.6825 & 0.2476 & 0.8122 & 0.8604 & 0.2786 \\
\hline Pythium spp. clade F & 0.7040 & 0.5386 & 0.0147 & 0.1564 & 0.7980 & 0.4278 & 0.0636 \\
\hline R. solani AG-8 & 0.0001 & 0.0030 & 0.1370 & 0.0038 & 0.0901 & 0.0365 & 0.0963 \\
\hline P. thornei & $<0.0001$ & 0.3304 & 0.6249 & 0.9119 & 0.9944 & 0.9969 & 0.9465 \\
\hline
\end{tabular}

${ }^{w}$ Analyses are for data grouped over 2 years of sampling (2013 and 2015) for all experiments except experiment 7, which was comprehensively sampled only during $2015 ;. .$. indicates comprehensive sampling data were collected only during 2015.

$\mathrm{x}$ Whole plot (Whole), subplot (Sub), and sub-subplot (Sub-sub).

y Experiment number, name, treatments, and pathogens. Experimental treatments are described in the Methods section. Treatments are abbreviated as the number of treatments for crop $(\mathrm{C})$, fertility $(\mathrm{F})$, physical location $(\mathrm{L})$, rotation phase $(\mathrm{P})$, cropping system $(\mathrm{S})$, tillage $(\mathrm{T})$, or year $(\mathrm{Y})$. Treatments are listed in the order in which they were applied for analysis (e.g., $2 \mathrm{P}, 6 \mathrm{~F}, 2 \mathrm{Y}$ indicates that rotation phase was the whole plot, fertility treatment was the subplot, and year was the subsubplot). Pathogens reported in this table are restricted to those for which at least one main treatment effect or one interaction was significant at $P<0.05$, as determined by analysis of variance.

$\mathrm{z}$ Two experiments (number 5 and number 8 ) were analyzed as randomized complete blocks. Therefore, main effects, from left to right, are first factor, second factor, and third factor. 
densities following wheat than fallow for all other management treatments (Table 4). The fertility-year interaction indicated a strong positive response to higher rainfall during 2015 compared with 2013 in the $0 \mathrm{~N}$ treatment $(0.4$ versus 3.4 nematodes/g) and smaller differences between years for all other treatments. The main treatment effects for fertility and year were also significant for P. neglectus (Table 2). Treatments had mean DNA densities of 19.8, 7.9, 5.5, $4.1,3.8$, and $1.9 \mathrm{pg} / \mathrm{g}$ in the manure, $90 \mathrm{~N}+$ burn, $45 \mathrm{~N}, 90 \mathrm{~N}$, pea, and $0 \mathrm{~N}$ treatments, respectively $\left(\mathrm{HSD}_{0.05}=4.5\right)$. The density was greater in the manure treatment following wheat than in all other treatments (Table 4). The density of $P$. neglectus was greater during the wetter (2015) than the drier (2013) year: 8.6 and 5.7 nematodes/g of soil, respectively $\left(\mathrm{HSD}_{0.05}=1.4\right)$.

There were no strong significant correlations $\left(R^{2}>0.7\right.$ and $P<$ 0.0001 ) among pathogens when the analyses included data from all treatments from each rotational phase and both years $(n=48)$. When data from individual years were evaluated there was a significant positive correlation between $G$. graminis var. tritici and $P$. neglectus during 2013 (Fig. 1). Therefore, this association between a fungal and nematode pathogen was detected in a mixture of samples taken from standing stubble following winter wheat plus soil that had been plowed prior to planting winter wheat during the previous autumn. The association was not improved when data were further restricted to include only the samplings made following the wheat phase of the rotation $(n=12)$.

Experiment 2: Tillage-fertility. Pathogens for which significant treatment differences were detected included $F$. culmorum, G. graminis var. tritici, Pythium spp., and P. neglectus (Table 2). For two of those pathogens, $F$. culmorum and $G$. graminis var. tritici, the inoculum densities were very low. For $F$. culmorum, there were no significant interactions among main effects but the fertility treatment significantly affected inoculum density (Table 2). The DNA concentration increased with increasing rates of $\mathrm{N}$ application: $0.3,1.0$, and $1.5 \mathrm{pg} / \mathrm{g}$ for the $45 \mathrm{~N}, 90 \mathrm{~N}$, and $135 \mathrm{~N}$ treatments, respectively $\left(\mathrm{HSD}_{0.05}=0.3\right)$. For $G$. graminis var. tritici, there were also no significant interactions among main effects but the tillage treatment significantly affected inoculum density (Table 2). The DNA concentration increased with increasing levels of straw retention at the soil surface: $0.1,0.2$, and $0.3 \mathrm{pg} / \mathrm{g}$ for the plow, disk, and sweep treatments, respectively $\left(\mathrm{HSD}_{0.05}=0.1\right)$.
Inoculum density of Pythium spp. was significantly affected by the tillage-year interaction (Table 2). The interaction reflected higher inoculum densities during the wettest year (2015), with the difference being much more pronounced in the disk and sweep treatments than in the plow treatment. Inoculum density for Pythium spp. was significantly affected by each of the three main variables (Table 2). Inoculum was greatest at the lowest $\mathrm{N}$ rates: 33,34 , and $21 \mathrm{pg} / \mathrm{g}$ $\left(\mathrm{HSD}_{0.05}=2\right)$ for the $45 \mathrm{~N}, 90 \mathrm{~N}$, and $135 \mathrm{~N}$ treatments, which

Table 4. Influence of fertility management variables on inoculum densities of four soilborne pathogens in a winter wheat-cultivated fallow rotation man-

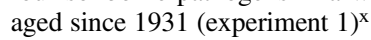

\begin{tabular}{llcccc}
\hline & & \multicolumn{3}{c}{ DNA (pg/g) } & \\
\cline { 3 - 5 } Treatment $^{\mathbf{y}}$ & Phase $^{\mathbf{z}}$ & $\mathbf{G g}$ & $\mathbf{P p}$ & $\mathbf{P y}$ & Pn $(\boldsymbol{n} / \mathbf{g})$ \\
\hline $0 \mathrm{~N}$ & Fallow & $0 \mathrm{~b}$ & $0 \mathrm{~b}$ & $10 \mathrm{~b}$ & $1 \mathrm{c}$ \\
$45 \mathrm{~N}$ & Fallow & $0 \mathrm{~b}$ & $0 \mathrm{~b}$ & $14 \mathrm{~b}$ & $3 \mathrm{c}$ \\
$90 \mathrm{~N}$ & Fallow & $0 \mathrm{~b}$ & $0 \mathrm{~b}$ & $15 \mathrm{~b}$ & $1 \mathrm{c}$ \\
$90 \mathrm{~N}+$ burn & Fallow & $0 \mathrm{~b}$ & $0 \mathrm{~b}$ & $9 \mathrm{~b}$ & $2 \mathrm{c}$ \\
Manure & Fallow & $1 \mathrm{~b}$ & $0 \mathrm{~b}$ & $54 \mathrm{a}$ & $13 \mathrm{~b}$ \\
Pea & Fallow & $1 \mathrm{~b}$ & $5 \mathrm{a}$ & $38 \mathrm{~b}$ & $4 \mathrm{c}$ \\
$0 \mathrm{~N}$ & Wheat & $0 \mathrm{~b}$ & $0 \mathrm{~b}$ & $16 \mathrm{~b}$ & $3 \mathrm{c}$ \\
$45 \mathrm{~N}$ & Wheat & $5 \mathrm{ab}$ & $0 \mathrm{~b}$ & $17 \mathrm{ab}$ & $8 \mathrm{bc}$ \\
$90 \mathrm{~N}$ & Wheat & $1 \mathrm{~b}$ & $0 \mathrm{~b}$ & $17 \mathrm{ab}$ & $7 \mathrm{bc}$ \\
$90 \mathrm{~N}+$ burn & Wheat & $18 \mathrm{a}$ & $0 \mathrm{~b}$ & $17 \mathrm{ab}$ & $14 \mathrm{~b}$ \\
Manure & Wheat & $8 \mathrm{ab}$ & $0 \mathrm{~b}$ & $24 \mathrm{~b}$ & $27 \mathrm{a}$ \\
Pea & Wheat & $2 \mathrm{~b}$ & $8 \mathrm{a}$ & $14 \mathrm{~b}$ & $4 \mathrm{c}$ \\
\hline
\end{tabular}

${ }^{\mathrm{x}}$ Data are 2-year means rounded to the nearest whole unit. Pathogens include Gaeumannomyces graminis var. tritici $(\mathrm{Gg})$, Phoma pinodella $(\mathrm{Pp})$, Pythium spp. clade F (Py), and Pratylenchus neglectus $(\mathrm{Pn} ; n=$ nematodes per gram). Numbers followed by the same letter within a column are not significantly different at $P=0.05$ according to Tukey's honestly significant different test.

y Treatments prior to planting wheat were no fertilizer $(0 \mathrm{~N})$, nitrogen $(\mathrm{N})$ at $45 \mathrm{~kg} / \mathrm{ha}(45 \mathrm{~N})$ or $90 \mathrm{~kg} / \mathrm{ha}(90 \mathrm{~N}), 90 \mathrm{~N}$ plus burning the wheat stubble before plowing ( $90 \mathrm{~N}+$ burn), application of $\mathrm{N}$ at $111 \mathrm{~kg} / \mathrm{ha}$ as cow manure (Manure), or application of $\mathrm{N}$ at $34 \mathrm{~kg} / \mathrm{ha}$ as pea vines (Pea), all since 1931 .

${ }^{\mathrm{z}}$ Rotational phase (fallow or wheat) preceding the date of sampling. Fallow was sampled during a 5-month-old seedling winter wheat crop planted after a 14-month fallow and Wheat was sampled midway into the fallow phase following a wheat crop harvested 7 months earlier.

Table 3. Soilborne pathogens and the range of inoculum densities per gram of soil detected by quantitative polymerase chain reaction assays on extracts from soils collected from various treatments of eight long-term experiments at the research center near Pendleton, $\mathrm{OR}^{\mathrm{u}}$

\begin{tabular}{|c|c|c|c|c|c|c|c|c|c|c|c|}
\hline \multirow[b]{2}{*}{ Experimenty } & \multicolumn{7}{|c|}{ Fungi (pg DNA/g) ${ }^{v}$} & \multicolumn{2}{|c|}{ Fungi $(c p / g)^{w}$} & \multicolumn{2}{|c|}{$\operatorname{Nema}(n / g)^{x}$} \\
\hline & Bs & Fc & Fp & Gg & $\mathbf{P p}$ & Py & Rs & $\mathbf{D t}^{\mathbf{z}}$ & $\mathbf{H e}^{\mathrm{z}}$ & Pn & $\mathbf{P t}$ \\
\hline 1. Fertility & nd & $0-2$ & $0-10$ & $0-18^{*}$ & $0-8^{*}$ & 9-38* & $0-12$ & nd & $0-29$ & $1-27 *$ & $0-1$ \\
\hline 2. Tillage & nd & $0-2 *$ & $\operatorname{tr}$ & $0-1^{*}$ & nd & $6-54 *$ & $0-7$ & nd & $0-1$ & $0-4^{*}$ & nd \\
\hline 3. Wheat-pea & nd & $0-3 *$ & $0-2$ & $1-2 *$ & $97-579 *$ & $47-111^{*}$ & $0-27 *$ & $0-3$ & $0-7$ & $0-13 *$ & $1-5^{*}$ \\
\hline 4. Annual & $0-33 *$ & $0-170^{*}$ & $2-60 *$ & $1-73 *$ & nd & $26-92 *$ & $0-4$ & $0-52$ & nd & $0-27 *$ & $0-27^{*}$ \\
\hline 5. Pasture & 0 & $7-12 *$ & $17-70$ & $9-31 *$ & nd & $20-49$ & $16-34^{*}$ & $35-163$ & 12 & $13-16$ & $0-1$ \\
\hline 6. Three-year & nd & $2-11$ & $0-20 *$ & $1-33$ & nd & $41-87$ & $0-44^{*}$ & nd & $0-578^{*}$ & $0-12 *$ & $4-19 *$ \\
\hline 7. Organic ${ }^{z}$ & $14-287$ & $1-4 *$ & $0-1$ & $6-10$ & $10-45$ & $145-295^{*}$ & $17-210^{*}$ & nd & nd & $1-7$ & $3-17^{*}$ \\
\hline 8. Winter & nd & $0-3 *$ & $1-19 *$ & $0-1$ & nd & $18-24 *$ & $0-79 *$ & nd & $0-3$ & $1-4$ & $0-1^{*}$ \\
\hline
\end{tabular}

$\mathrm{u}$ With the few exceptions noted in the table, data are the ranges among means of replicates for individual treatments averaged over both years of sampling (2013 and 2015), with each 2-year mean rounded to the nearest whole unit for individual treatments within each experiment; nd $=$ not detected; $*=$ significant differences occurred among treatments; and tr $=$ trace, indicating that the pathogen was detected in at least one treatment but at a concentration of DNA at less than $0.5 \mathrm{pg} / \mathrm{g}$ of soil.

$\checkmark$ Fungal pathogens included Bipolaris sorokiniana $(\mathrm{Bs})$, Fusarium culmorum $(\mathrm{Fc})$, F. pseudograminearum $(\mathrm{Fp})$, Gaeumannomyces graminis var. tritici $(\mathrm{Gg})$, Phoma pinodella (Pp), Pythium spp. clade F (Py), Rhizoctonia solani AG-8 (Rs), Drechslera tritici-repentis (Dt), and Helgardia acuformis plus H. herpotrichoides (He).

${ }^{w}$ Units for Dt and He were reported as copies of DNA per gram (cp/g) and were rounded to the nearest thousand for reporting in this table (1,000 copies of DNA/g).

x Parasitic nematodes (Nema; $n=$ number per gram) included Pratylenchus neglectus $(\mathrm{Pn})$ and $P$. thornei $(\mathrm{Pt})$

y Crops produced in each experiment included winter wheat (WW), spring wheat (SW), spring barley (SB), spring pea (SP), perennial grasses (PG), and mixtures of wheat with either clover (WC) or medic (WM). Rotational management phases sampled included cultivated fallow (CuF) and noncultivated chemical fallow (no-till, ChF). Experiment crop or management phase prior to sampling were 1, fertility management (WW \& CuF); 2, tillage-fertility (WW); 3, wheat-pea rotation (WW \& SP); 4, annual cereals (WW, SW \& SB); 5, pasture versus wheat (PG \& WW); 6, 3-year rotation (WW, SW \& ChF); 7, organic wheat (WC, WM); and 8, winter wheat tillage (WW).

z Data for Dt and He were reported only during 2015. Data for the organic wheat experiment are also for 2015 only because clover and medic treatments in the two cropping systems were composited during 2013. 
was particularly evident in the sweep treatment (Table 5). Inoculum of Pythium spp. also increased with increasing amounts of surface residue: 7,36 , and $45 \mathrm{pg} / \mathrm{g}$ for the plow, disk, and sweep treatments, respectively $\left(\mathrm{HSD}_{0.05}=6\right)$. As noted earlier, the inoculum density was greater during the wetter than the drier year: 35.3 versus $23.2 \mathrm{pg} / \mathrm{g}$ during 2015 and 2013 , respectively $\left(\mathrm{HSD}_{0.05}=5.0\right)$.

Inoculum of $P$. neglectus was significantly influenced by the fertility-year interaction (Table 2), which reflected the elevation of nematode density during the wetter year (2015), particularly at the lowest $\mathrm{N}$ rate $(45 \mathrm{~N})$ compared with the higher $\mathrm{N}$ rates. Although the densities of $P$. neglectus were rather low throughout this experiment (Table 3), there were significant differences for the main treatment effects of fertility and year (Table 2). Densities were greater at the lowest $\mathrm{N}$ rate: $2.5,0.9$, and 0.2 nematodes/g of soil for the $45 \mathrm{~N}$, $90 \mathrm{~N}$, and $135 \mathrm{~N}$ treatments, respectively $\left(\mathrm{HSD}_{0.05}=0.9\right)$. The highest densities of $P$. neglectus occurred in the $45 \mathrm{~N}$ fertility rates in the sweep and disk tillage blocks (Table 5). The nematode density was higher during the wetter than the drier year: 1.8 versus 0.7 nematodes/g of soil during 2015 and 2013, respectively $\left(\mathrm{HSD}_{0.05}=0.7\right)$.

There were no strong significant correlations $\left(R^{2}>0.7\right.$ and $P<$ 0.0001 ) among pathogens when the analyses included data from all fertility and tillage treatments during both years $(n=54)$ or when data were analyzed by individual tillage treatments and years $(n=9)$.

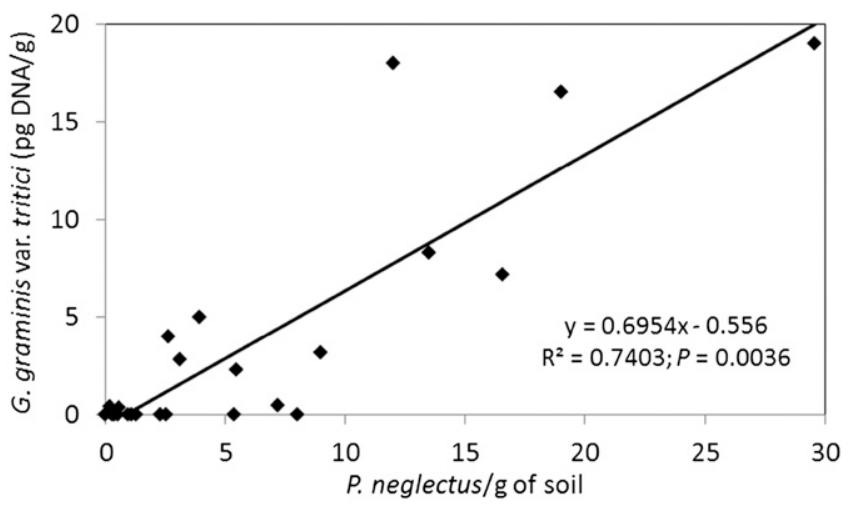

Fig. 1. Association between Gaeumannomyces graminis var. tritici and Pratylenchus neglectus following the winter wheat rotational phase of the fertility management experiment (experiment 1) during 2013.

Table 5. Influence of fertility-tillage variables on inoculum densities of three soilborne pathogens in a winter wheat-cultivated fallow rotation managed since $1940\left(\right.$ experiment 2) ${ }^{\mathrm{x}}$

\begin{tabular}{lllcc}
\hline & & \multicolumn{2}{c}{ DNA $(\mathbf{p g} / \mathbf{g})$} & \\
\cline { 3 - 4 } Treatment $^{\mathbf{y}}$ & Tillage $^{\mathbf{z}}$ & Fc & Py & Pn $(\boldsymbol{n} / \mathbf{g})$ \\
\hline $45 \mathrm{~N}$ & Plow & $0 \mathrm{c}$ & $6 \mathrm{~d}$ & $1 \mathrm{~cd}$ \\
$90 \mathrm{~N}$ & Plow & $1 \mathrm{~b}$ & $8 \mathrm{~cd}$ & $0 \mathrm{~d}$ \\
$135 \mathrm{~N}$ & Plow & $1 \mathrm{~b}$ & $6 \mathrm{~d}$ & $0 \mathrm{~d}$ \\
$45 \mathrm{~N}$ & Disk & $0 \mathrm{c}$ & $39 \mathrm{ab}$ & $4 \mathrm{a}$ \\
$90 \mathrm{~N}$ & Disk & $1 \mathrm{~b}$ & $44 \mathrm{ab}$ & $2 \mathrm{bc}$ \\
$135 \mathrm{~N}$ & Disk & $2 \mathrm{a}$ & $26 \mathrm{bcd}$ & $0 \mathrm{~d}$ \\
$45 \mathrm{~N}$ & Sweep & $0 \mathrm{c}$ & $54 \mathrm{a}$ & $3 \mathrm{ab}$ \\
$90 \mathrm{~N}$ & Sweep & $1 \mathrm{~b}$ & $49 \mathrm{ab}$ & $1 \mathrm{~cd}$ \\
$135 \mathrm{~N}$ & Sweep & $2 \mathrm{a}$ & $31 \mathrm{abc}$ & $0 \mathrm{~d}$ \\
\hline
\end{tabular}

${ }^{x}$ Data are 2-year means rounded to the nearest whole unit. Pathogens include Fusarium culmorum $(\mathrm{Fc})$, Pythium spp. clade F (Py), and Pratylenchus neglectus ( $\mathrm{Pn} ; n=$ nematodes per gram). Numbers followed by the same letter within a column are not significantly different at $P=0.05$ according to Tukey's honestly significant different test.

y Treatments were nitrogen $(\mathrm{N})$ at $45 \mathrm{~kg} / \mathrm{ha}(45 \mathrm{~N}), 90 \mathrm{~kg} / \mathrm{ha}(90 \mathrm{~N})$, or 135 $\mathrm{kg} / \mathrm{ha}(135 \mathrm{~N})$, since 1940 , applied during the fallow year before planting winter wheat.

${ }^{\mathrm{z}}$ Tillage consisted of moldboard plowing (Plow), offset disking (Disk), or subsurface sweeps (Sweep) conducted during the spring of the fallow year of the 2-year winter wheat-fallow rotation. Samples were collected in the spring when winter wheat seedlings were 5 months old, following a 14-month fallow period since the last wheat crop had been harvested.
Experiment 3: Wheat-pea rotation. Significant interactions among main treatment variables were common (10 of 28 possible interactions; $36 \%$ ) and occurred for seven pathogens: F. culmorum, G. graminis var. tritici, Phoma pinodella, Pythium spp. clade F, $R$. solani AG-8, Pratylenchus neglectus, and P. thornei (Table 2). Inoculum concentrations for both $F$. culmorum and $G$. graminis var. tritici were very low (Table 3), as had also occurred in experiment 2.

For $F$. culmorum, the significant crop-tillage-year interaction reflected complex effects of main treatment variables. The inoculum density was greater during the wetter than the drier year in two treatments: following pea in the conservation tillage (4.6 versus $0.5 \mathrm{pg} / \mathrm{g}$ for 2015 and 2013, respectively) and following wheat in the plow treatment (5.1 versus $0 \mathrm{pg} / \mathrm{g}$ for 2015 and 2013, respectively). The opposite relationship (e.g., greater inoculum density during the drier than the wetter year) occurred following wheat in the conservation tillage (5.0 versus $1.5 \mathrm{pg} / \mathrm{g}$ for 2013 and 2015, respectively) and following pea in the plow treatment $(0.4$ versus $0 \mathrm{pg} / \mathrm{g}$ for 2013 and 2015 , respectively). There were no significant differences among main treatments for $F$. culmorum (Table 2).

A significant tillage-year interaction for G. graminis var. tritici (Table 2) indicated that inoculum density was greater during the drier year than the wetter year in the conservation tillage treatment $(1.8$ versus $1.3 \mathrm{pg} / \mathrm{g}$ for 2013 and 2015, respectively) and was greater during the wetter than the drier year in the plow treatment ( 4.7 versus 3.2 $\mathrm{pg} / \mathrm{g}$ for 2015 and 2013, respectively). There were no significant differences among main treatments for G. graminis var. tritici (Table 2).

Inoculum of Phoma pinodella was significantly influenced by the crop-tillage interaction and by each of the main treatment effects (Table 2). The interaction showed that differences in inoculum density were much greater following pea than following wheat in the conservation tillage treatment (579 versus $96 \mathrm{pg} / \mathrm{g}$, respectively) as compared with the plow treatment (160 versus $119 \mathrm{pg} / \mathrm{g}$, respectively). Inoculum levels were higher during the wetter than the drier sampling period ( 321 versus $156 \mathrm{pg} / \mathrm{g}$, respectively; $\mathrm{HSD}_{0.05}=83$ ). The concentration was also greater in the conservation than in the plow treatment (338 versus $139 \mathrm{pg} / \mathrm{g}$, respectively; $\mathrm{HSD}_{0.05}=83$ ) and was greater following pea than wheat (369 versus $108 \mathrm{pg} / \mathrm{g}$, respectively; $\mathrm{HSD}_{0.05}=83$ ). The inoculum concentration of $P$. pinodella was significantly higher in the conservation tillage system following pea than for any of the other combinations of treatments (Table 6).

Pythium spp. clade $\mathrm{F}$ was significantly influenced by three interactions: crop-tillage, crop-year, and tillage-year (Table 2). The crop-tillage interaction indicated that inoculum density was greater following pea than wheat in the conservation tillage treatment (111 versus $47 \mathrm{pg} / \mathrm{g}$, respectively) and was greater following wheat than pea in the plow treatment (93 versus $75 \mathrm{pg} / \mathrm{g}$, respectively). The

Table 6. Influence of previous crop and tillage system on inoculum densities of seven soilborne pathogens in a winter wheat-spring pea rotation managed since 1963 (experiment 3)

\begin{tabular}{|c|c|c|c|c|c|c|c|c|}
\hline \multirow[b]{2}{*}{ Crop $^{y}$} & \multirow[b]{2}{*}{ Till $^{z}$} & \multicolumn{5}{|c|}{ DNA (pg/g) } & \multicolumn{2}{|c|}{ Nema $(n / g$} \\
\hline & & Fc & Gg & $\mathbf{P p}$ & Py & Rs & Pn & $\mathbf{P t}$ \\
\hline Pea & Cons & $3 \mathrm{a}$ & $2 \mathrm{a}$ & $579 a$ & $111 \mathrm{a}$ & $0 \mathrm{~b}$ & $0 \mathrm{c}$ & \\
\hline Wheat & Cons & $3 \mathrm{a}$ & $1 \mathrm{a}$ & $97 \mathrm{~b}$ & $47 \mathrm{a}$ & $0 \mathrm{~b}$ & 2 & \\
\hline Pea & Plow & $0 \mathrm{a}$ & $1 \mathrm{a}$ & $160 \mathrm{~b}$ & $75 a$ & $2 \mathrm{~b}$ & $2 \mathrm{~b}$ & 3 \\
\hline Wheat & Plow & $3 a$ & $1 \mathrm{a}$ & $119 \mathrm{~b}$ & $93 \mathrm{a}$ & $27 \mathrm{a}$ & $13 \mathrm{a}$ & 5 \\
\hline
\end{tabular}

${ }^{\mathrm{x}}$ Data are 2-year means rounded to the nearest whole unit. Pathogens include Fusarium culmorum $(\mathrm{Fc})$, Gaeumannomyces graminis var. tritici $(\mathrm{Gg})$, Phoma pinodella (Pp), Pythium spp. clade $\mathrm{F}(\mathrm{Py})$, Rhizoctonia solani AG-8 (Rs), Pratylenchus neglectus $(\mathrm{Pn})$, and $P$. thornei $(\mathrm{Pt}) ;$ nema $=$ nematodes ( $n=$ number per gram). Numbers followed by the same letter within a column are not significantly different at $P=0.05$ according to Tukey's honestly significant different test.

y The previous crop before sampling was either spring pea (Pea) or winter wheat (Wheat).

${ }^{\mathrm{z}}$ Tillage (Till) was either by sweep tillage before wheat and no tillage before pea (conservation [Cons]) or by moldboard plowing before each crop (Plow). 
crop-year interaction indicated that inoculum density was greater during the wetter than the drier year following pea (110 versus 76 pg/g for 2015 and 2013, respectively) and was greater during the drier year than the wetter year following wheat (106 versus 34 $\mathrm{pg} / \mathrm{g}$ for 2013 and 2015, respectively). The tillage-year interaction indicated that inoculum density was greater during the wetter year than the drier year in the conservation tillage treatment (108 versus $50 \mathrm{pg} / \mathrm{g}$ for 2015 and 2013, respectively) and was greater during the drier than the wetter year in the plow treatment (131 versus 37 $\mathrm{pg} / \mathrm{g}$ for 2013 and 2015, respectively). None of the main treatment effects were significant for Pythium spp. but the nearly significant effect of crop (Table 2) indicated a trend for Pythium spp. to be more prevalent following pea than wheat ( 93 versus $70 \mathrm{pg} / \mathrm{g}$, respectively; $\mathrm{HSD}_{0.05}=24$ ).

For $R$. solani AG-8, the crop-tillage interaction and the main effect of tillage were significant (Table 2). The crop-tillage interaction was due to a great variability in inoculum density between tillage treatments following wheat but not following pea. In the plow and conservation treatments, the inoculum densities were 27 versus 0.2 $\mathrm{pg} / \mathrm{g}$, respectively, following wheat and 2.1 versus $0.0 \mathrm{pg} / \mathrm{g}$, respectively, following pea (Table 6). Inoculum of $R$. solani AG-8 was greater in the plow than in the conservation treatment (17.2 and $0.1 \mathrm{pg} / \mathrm{g}$, respectively; $\mathrm{HSD}_{0.05}=11$ ).

Densities of both Pratylenchus neglectus and P. thornei were significantly affected by crop-tillage interactions, and the tillage-year interaction was also significant for $P$. thornei (Table 2). The croptillage interactions indicated that nematode densities were greater in the plow than in the conservation treatments following wheat (13.1 versus 2.3 nematodes/g for P. neglectus and 5.1 versus 2.0 nematodes $/ g$ for $P$. thornei), whereas the densities were not as strongly influenced by tillage treatments following pea (1.8 versus 0.1 nematodes/g for $P$. neglectus and 2.8 versus 1.1 nematodes $/ g$ for $P$. thornei). The tillage-year interaction occurred because the inoculum densities differed more and in opposite manners over years in the plow treatment (4.7 versus 3.2 nematodes/g during 2015 and 2013) than in the conservation treatment (1.3 versus 1.8 nematodes/g during 2015 and 2013). The significant main treatment effect of crop for each pathogen (Table 2) showed that there was greater inoculum density following wheat than pea: 7.8 versus 0.9 nematodes/g, respectively, for P. neglectus $\left(\mathrm{HSD}_{0.05}=1.0\right)$ and 3.5 versus 2.5 nematodes/g, respectively, for $P$. thornei $\left(\mathrm{HSD}_{0.05}=\right.$ 0.4 ). The significant treatment effect of tillage for both species showed that the inoculum density was greater in the plow than in the conservation treatment: 7.5 versus 1.2 nematodes/g, respectively, for $P$. neglectus $\left(\mathrm{HSD}_{0.05}=1.0\right.$ ) and 4.0 versus 1.5 nematodes $/ \mathrm{g}$, respectively, for $P$. thornei $\left(\mathrm{HSD}_{0.05}=0.4\right)$. In particular, the density was higher following wheat in the plow treatment than in any of the other combinations of tillage and crop treatments (Table 6).

D. tritici-repentis was detected in this experiment but was found only in the conservation tillage treatment following a crop of winter wheat during 2015; this pathogen was not included among assays reported during 2013 (Table 3).

When all data for the experiment were compared $(n=24)$, there were strong, significantly positive correlations $\left(R^{2}>0.7\right.$ and $P<$ 0.0001 ) between $P$. neglectus and $P$. thornei and also between $R$. solani AG-8 and each of the Pratylenchus spp. The latter association was also strong for the total density of Pratylenchus spp. in the plow treatment following the wheat phase of the rotation (Fig. 2). The strong positive associations between the two Pratylenchus spp. and between $R$. solani AG-8 and Pratylenchus spp. also occurred across tillage and rotational phase treatments during each year of testing, and also across tillage treatments and years following wheat crops. When analyzed across all combinations of tillage and rotational phase treatments, associations between Pythium spp. clade F and each of the Pratylenchus spp. were significantly positive during the drier year of 2013 and significantly negative during the wetter year of 2015. These correlations were strongest when the two Pratylenchus spp. were added together and $\log _{\mathrm{n}}$-transformed before the inoculum density of Pythium spp. was regressed against the nematode density (Fig. 2). As explained for the association reported for experiment 1, the association between Pythium spp. and Pratylenchus spp. in experiment 3 resulted from a mixture of samples collected from standing stubble and soil plowed prior to planting winter wheat.

Experiment 4: Annual cereals. Treatment interactions (19 of 28 possible; $68 \%$ ) were significant and occurred for seven pathogens: B. sorokiniana, F. culmorum, F. pseudograminearum, G. graminis var. tritici, Pythium spp. clade F, P. neglectus, and $P$. thornei (Table 2). Ranges of inoculum density included substantially high concentrations for each of the pathogens in this experiment (Table 3 ).

The tillage-crop interaction for $B$. sorokiniana indicated that the inoculum density was greater in the no-till than in cultivated spring barley (11.7 versus $1.0 \mathrm{pg} / \mathrm{g}$ ), greater in cultivated than in no-till spring wheat ( 33.1 versus $9.8 \mathrm{pg} / \mathrm{g}$ ), and not detected at any time in winter wheat (Table 7). The significant treatment effect of crop reflected a far greater DNA density in spring wheat than in spring barley, and the absence of detection in winter wheat: 21.5, 6.4, and $0.0 \mathrm{pg} / \mathrm{g}$, respectively $\left(\mathrm{HSD}_{0.05}=7.1\right)$. When all tillage and crop treatment combinations were compared, inoculum of $B$. sorokiniana was significantly greater in spring wheat of the plowed treatment than in all other combinations (Table 7).

Inoculum density of $F$. culmorum differed significantly for all possible interactions of main treatments as well as for the main treatment variables of crop and year (Table 2). The tillage-crop interaction indicated that cultivated soil contained more inoculum of $F$. culmorum than no-till soil for spring wheat ( 95 versus $3 \mathrm{pg} / \mathrm{g}$ ) and the opposite occurred for spring barley (0 versus $170 \mathrm{pg} / \mathrm{g}$ ) and winter wheat ( 1 versus $14 \mathrm{pg} / \mathrm{g}$ ). The tillage-year interaction indicated that inoculum density was greater in the no-till than cultivated block during the wetter year (116 versus $37 \mathrm{pg} / \mathrm{g}$ ) and the opposite occurred during the drier year ( 9 versus $27 \mathrm{pg} / \mathrm{g}$ ). The crop-year interaction indicated that inoculum of $F$. culmorum was greater during the wetter than the drier year for each crop but differences were greater across years for spring barley (157 versus 13 pg/g during 2015 and 2013, respectively) than


Fig. 2. Associations between the concentration of fungal DNA and the density of total Pratylenchus spp. (Pratylenchus neglectus plus $P$. thornei) in the winter wheat-spring pea experiment (experiment 3): (top) Rhizoctonia solani AG-8 in the plow tillage treatment following the wheat phase of the rotation and (bottom) Pythium spp. clade $F$ in all tillage-crop phase combinations during individual years (2013 and 2015) of sampling. 
for spring wheat (58 versus $40 \mathrm{pg} / \mathrm{g}$ ) or winter wheat (14 versus $1 \mathrm{pg} / \mathrm{g}$ ). A tillage-crop-year interaction reflected that the inoculum concentration during 2013 was high only in the cultivated spring wheat, in contrast to high concentrations in both cultivated spring wheat and no-till spring barley during 2015 and an intermediate concentration in the no-till winter wheat during 2015. A significant main effect of crop indicated that inoculum of $F$. culmorum was greater in spring barley than in spring wheat and was greater in spring wheat than in winter wheat: 85,49 , and $8 \mathrm{pg} / \mathrm{g}$, respectively $\left(\mathrm{HSD}_{0.05}=\right.$ $35)$. The significant main effect of year indicated that inoculum density of $F$. culmorum was greater during the wetter than the drier year ( 77 versus $18 \mathrm{pg} / \mathrm{g} ; \mathrm{HSD}_{0.05}=29$ ). When all tillage and crop treatment combinations were compared, inoculum of $F$. culmorum was significantly greater in spring barley of the plowed treatment than in all except one other combination (Table 7); the exception was an intermediate concentration of inoculum occurring in the winter wheat of the no-till treatment.

For $F$. pseudograminearum, the significant tillage-crop interaction (Table 2) indicated that inoculum was much greater in cultivated than no-till soils for spring wheat (60 versus $2 \mathrm{pg} / \mathrm{g}$ ) but did not vary greatly among tillage treatments for spring barley (4 versus $6 \mathrm{pg} / \mathrm{g}$ ) and winter wheat $(5$ versus $11 \mathrm{pg} / \mathrm{g}$ ). The significant effect of previous crop indicated that inoculum was greater after spring wheat than after winter wheat or spring barley: 31,8 , and $5 \mathrm{pg} / \mathrm{g}$, respectively $\left(\mathrm{HSD}_{0.05}=18\right)$. Although the main effects of year and tillage were not significant (Table 2), there was a strong trend for inoculum of $F$. pseudograminearum to be higher during the drier than the wetter year (21 versus $8 \mathrm{pg} / \mathrm{g}$ during 2013 and 2015, respectively).

All possible interactions and main treatments were significant for G. graminis var. tritici (Table 2). The tillage-crop interaction indicated that inoculum was greater in cultivated than no-till soils for each crop but the magnitude of difference varied for winter wheat ( 73 versus $1 \mathrm{pg} / \mathrm{g}$ ), spring wheat (15 versus $1 \mathrm{pg} / \mathrm{g}$ ), and spring barley (10 versus $1 \mathrm{pg} / \mathrm{g}$ ). The tillage-year interaction indicated that inoculum density was higher in the cultivated than in the no-till block during both years but the difference was greater during the drier year (49 versus $0 \mathrm{pg} / \mathrm{g}$ during 2013) than during the wetter year (17 versus 2 $\mathrm{pg} / \mathrm{g}$ during 2015). The crop-year interaction indicated that inoculum in winter wheat was considerably greater during 2013 than 2015 (61 versus $12 \mathrm{pg} / \mathrm{g}$ ) but did not differ across years for spring wheat (7 versus $9 \mathrm{pg} / \mathrm{g}$ ) or spring barley (4 versus $7 \mathrm{pg} / \mathrm{g}$ ). The tillage-crop-year interaction occurred because the inoculum density was always higher in cultivated than in no-till blocks but the magnitude of that difference was especially pronounced in winter wheat during 2013 . The significant main treatment effect of crop (Table 2) indicated that winter wheat had far greater inoculum than spring wheat or spring barley:

Table 7. Influence of cereals planted annually without rotation into either cultivated or noncultivated soils on inoculum densities of seven soilborne pathogens (experiment 4$)^{\mathrm{x}}$

\begin{tabular}{|c|c|c|c|c|c|c|c|c|}
\hline \multirow[b]{2}{*}{ Crop $^{y}$} & \multirow[b]{2}{*}{ Tillage $^{\mathrm{z}}$} & \multicolumn{5}{|c|}{ DNA (pg/g) } & \multicolumn{2}{|c|}{$\operatorname{Nema}(n / g)$} \\
\hline & & Bs & Fc & Fp & Gg & Py & Pn & $\mathbf{P t}$ \\
\hline SB & Plow & $1 \mathrm{~b}$ & $0 \mathrm{~b}$ & $4 \mathrm{~b}$ & $10 \mathrm{~b}$ & $92 \mathrm{a}$ & $0 \mathrm{c}$ & $27 \mathrm{a}$ \\
\hline SW & Plow & $33 \mathrm{a}$ & $1 \mathrm{~b}$ & $60 \mathrm{a}$ & $15 \mathrm{~b}$ & $90 \mathrm{ab}$ & $1 \mathrm{c}$ & $5 c$ \\
\hline WW & Plow & $0 \mathrm{~b}$ & $95 \mathrm{ab}$ & $5 \mathrm{~b}$ & $76 \mathrm{a}$ & $28 \mathrm{ab}$ & $27 \mathrm{a}$ & $0 \mathrm{c}$ \\
\hline SB & No-till & $12 \mathrm{~b}$ & $170 \mathrm{a}$ & $6 \mathrm{~b}$ & $1 \mathrm{~b}$ & $44 \mathrm{ab}$ & $4 \mathrm{c}$ & $8 \mathrm{bc}$ \\
\hline SW & No-till & $10 \mathrm{~b}$ & $3 \mathrm{~b}$ & $2 \mathrm{~b}$ & $1 \mathrm{~b}$ & $57 \mathrm{ab}$ & $6 \mathrm{c}$ & $19 a b$ \\
\hline WW & No-till & $0 \mathrm{~b}$ & $14 \mathrm{~b}$ & $11 \mathrm{~b}$ & $1 \mathrm{~b}$ & $26 \mathrm{~b}$ & $18 \mathrm{~b}$ & $3 c$ \\
\hline
\end{tabular}

${ }^{\mathrm{x}}$ Data are 2-year means rounded to the nearest whole unit. Pathogens include Bipolaris sorokiniana (Bs), Fusarium culmorum $(\mathrm{Fc}), F$. pseudograminearum (Fp), Gaeumannomyces graminis var. tritici $(\mathrm{Gg})$, Pythium spp. clade $\mathrm{F}$ (Py), Pratylenchus neglectus $(\mathrm{Pn})$, and $P$. thornei $(\mathrm{Pt})$; nema $=$ nematodes ( $n=$ number per gram). Numbers followed by the same letter within a column are not significantly different at $P=0.05$ according to Tukey's honestly significant different test.

y Crops planted annually into separate subplots were spring barley (SB), spring wheat (SW), and winter wheat (WW).

${ }^{\mathrm{z}}$ Blocks were managed either with inversion tillage using a moldboard plow (Plow) since 1931 or without tillage (No-till) since 1997.
37,8 , and $5 \mathrm{pg} / \mathrm{g}$, respectively $\left(\mathrm{HSD}_{0.05}=5\right.$ ). Inoculum density of $G$. graminis var. tritici was also greater in the cultivated block than in the no-till block (32 versus $\left.1 \mathrm{pg} / \mathrm{g} ; \mathrm{HSD}_{0.05}=4\right)$, and was greater during the drier than the wetter year ( 24 versus $9 \mathrm{pg} / \mathrm{g} ; \mathrm{HSD}_{0.05}=4$ ). When all tillage and crop treatment combinations were compared, inoculum of $G$. graminis var. tritici was significantly greater in winter wheat of the plowed treatment than in all other combinations (Table 7).

Inoculum density of Pythium spp. was significantly affected by tillage-crop and tillage-crop-year interactions, and also by the main effect of crop (Table 2). The tillage-crop interaction showed that the inoculum density was greater in cultivated than in no-till spring barley ( 92 versus $44 \mathrm{pg} / \mathrm{g}$ ) and spring wheat ( 90 versus $57 \mathrm{pg} / \mathrm{g}$ ) but did not differ among tillage treatments for winter wheat (28 versus 26 $\mathrm{pg} / \mathrm{g}$ ). The tillage-crop-year interaction indicated that the DNA concentration was greater in cultivated than in no-till blocks during both years for spring barley but inoculum in spring wheat was greater in no-till than cultivated blocks during 2013 and the opposite occurred during 2015. In contrast, in winter wheat, the inoculum density of Pythium spp. was greater in no-till than cultivated blocks during 2015 and the opposite occurred during 2013. Inoculum density of Pythium spp. was also greater in spring wheat and spring barley than in winter wheat $\left(74,68\right.$, and $27 \mathrm{pg} / \mathrm{g}$, respectively; $\left.\mathrm{HSD}_{0.05}=18\right)$. When all crop and tillage treatment combinations were compared, inoculum of Pythium spp. clade F was significantly greater in spring barley of the plowed treatment than in winter wheat of the no-till treatment, and all other treatment combinations had intermediate concentrations of inoculum (Table 7).

The density of $P$. neglectus was significantly affected by the tillageyear, crop-year, and tillage-crop-year interactions and by the main effects of crop and year (Table 2). The tillage-year interaction indicated that inoculum density was greater in cultivated than no-till blocks during the drier year $(9.2$ versus 8.1 nematodes/g during 2013) and was greater in no-till than cultivated blocks during the wetter year (10.7 versus 9.4 nematodes/g during 2015). The crop-year interaction indicated that inoculum density was greater in the wetter than the drier year for winter wheat (23 versus 21 nematodes/g) and spring wheat (5 versus 2 nematodes/g) but the opposite occurred for spring barley ( 2 versus 3 nematodes $/ g$ ). The tillage-crop-year interaction indicated near equal numbers of $P$. neglectus each year in each of the three cultivated crops and different densities each year in each of the no-till cereals, with densities being high during the wetter year for spring wheat and spring barley, and lower during the wetter year for spring barley. The significant main treatment effects for crop and year indicated that a far higher density of $P$. neglectus occurred in winter wheat than in spring wheat or spring barley: 22,4 , and 2 nematodes/g of soil, respectively $\left(\mathrm{HSD}_{0.05}=8\right)$; and that the density was higher during 2015 than during 2013: 10.1 versus 8.7 nematodes/g, respectively $\left(\mathrm{HSD}_{0.05}=0.5\right)$. When all tillage and crop treatment combinations were compared, the density of $P$. neglectus was significantly greater in winter wheat of the plowed treatment than in all other combinations, and was also higher in the winter wheat of the no-till treatment than for all treatments that included spring wheat or spring barley (Table 7).

Inoculum density of $P$. thornei was significantly affected by all possible interactions as well as by the main effects of crop and year (Table 2). The tillage-crop interaction indicated that inoculum was greater in cultivated than in no-till blocks for spring barley ( 27 versus 8 nematodes/g of soil) and the opposite occurred for spring wheat ( 5 versus 19 nematodes/g of soil) and winter wheat ( 0 versus 3 nematodes/g of soil). The tillage-year interaction indicated that inoculum density was unaffected by the year in cultivated soil (11 and 11 nematodes/g of soil) but, in the no-till block, the density was greater during the wetter than the drier year (13 versus 7 nematodes/g of soil during 2015 and 2013, respectively). The crop-year interaction indicated that inoculum densities differed between 2013 and 2015 for spring wheat (5 versus 19 nematodes/g of soil) but not for spring barley (18 versus 17 nematodes/g of soil) or winter wheat (2 versus 1 nematodes/g of soil). The crop-tillage-year interaction suggested that the density of $P$. thornei was higher in the cultivated than 
no-till spring barley during both years and was higher in no-till than in cultivated spring wheat and winter wheat during both years. The significant main effect of crop indicated that $P$. thornei numbers were greater in spring barley and spring wheat than in winter wheat: 17.7, 12.0 , and 1.5 nematodes/g of soil, respectively $\left(\mathrm{HSD}_{0.05}=6.1\right)$. The main effect of year indicated that $P$. thornei was more prevalent during 2015 than during 2013: 12.2 versus 8.6 nematodes/g of soil, respectively $\left(\mathrm{HSD}_{0.05}=2.5\right)$. When all tillage and crop treatment combinations were compared, the density of $P$. thornei was significantly greater in spring barley of the plowed treatment than in all except one other combination, and the density was also high in the spring wheat and spring barley of the no-till treatment (Table 7).

Inoculum of $D$. tritici-repentis was detected in this experiment (Table 3 ) but it was only found in one replicate of the no-till annual spring wheat during 2015. In that replicate, the pathogen was detected at a high concentration (52,022 copies of DNA/g of soil). This pathogen was not included among assays reported during 2013.

When all data for the experiment were grouped (two tillage and three crop treatments over 2 years; $n=24$ ), there were no strong significant correlations $\left(R^{2}>0.7\right.$ and $\left.P<0.0001\right)$ between pathogens. However, many potentially important associations were revealed when data were analyzed by crop and, particularly, when the crop was evaluated by either tillage treatment or year. A strong positive association occurred in spring wheat between $F$. culmorum and G. graminis var. tritici when data were grouped for both tillage treatments and both sampling years (Fig. 3). Samples were collected directly in rows of standing stubble about 7 months after harvest. The relationship between $P$. neglectus and $P$. thorne $i$ was positive for spring wheat and negative for spring barley (Fig. 3). Although not significant, a negative trend between these pathogens was also detected in winter wheat. Associations commonly occurred between the nematodes and the primary root-invading fungal pathogens. Examples of the most significant of these associations are shown in Figure 4. For specific combinations of crop, tillage, and year, significant positive or negative associations were shown between the total Pratylenchus spp. density and the concentration of DNA of G. graminis var. tritici, Pythium spp. clade F, $R$. solani AG-8, B. sorokiniana, and total Fusarium spp. (F. culmorum plus F. pseudograminearum).

Experiment 5: Pasture versus wheat. The crop-year interaction and each of the main treatment effects were significant for G. graminis var. tritici (Table 2). The interaction indicated that the concentration of DNA was greater in the drier year (2013) than in the wetter year (2015) in wheat (61 and $2 \mathrm{pg} / \mathrm{g}$ of soil, respectively) and was much less variable in the pasture (14 and $4 \mathrm{pg} / \mathrm{g}$, respectively).

One or both main treatment effects were significant for each of the three pathogens shown in Table 2. For F. culmorum, the inoculum density was greater in winter wheat than in pasture: 70 versus 7 $\mathrm{pg} / \mathrm{g}$, respectively $\left(\mathrm{HSD}_{0.05}=61\right)$. There was a greater concentration of G. graminis var. tritici DNA in winter wheat than in pasture ( 31 versus $9 \mathrm{pg} / \mathrm{g}$, respectively; $\mathrm{HSD}_{0.05}=21$ ) and the inoculum density was greater during 2013 than 2015 (38 versus 3 pg/g, respectively; $\mathrm{HSD}_{0.05}=23$ ). For $R$. solani AG- 8 , the inoculum density was greater during the wetter than the drier year: 8 versus $42 \mathrm{pg} / \mathrm{g}$ during 2013 and 2015 , respectively $\left(\mathrm{HSD}_{0.05}=31\right)$. This differential effect occurred in both wheat ( 4 and $64 \mathrm{pg} / \mathrm{g}$, respectively) and pasture (12 and $20 \mathrm{pg} / \mathrm{g}$, respectively). There were no significant correlations among DNA of pathogens in this experiment.

Experiment 6: Three-year rotation. Pathogens for which significant treatment differences or interactions were detected included $F$. pseudograminearum, Helgardia spp., $R$. solani AG-8, P. neglectus, and $P$. thornei (Table 2). Significant interactions among treatments occurred for all except $F$. pseudograminearum and $R$. solani AG-8. The inoculum density of $F$. pseudograminearum was significantly affected only by the phase of the rotation (Table 2 ). The greatest amount of inoculum occurred following winter wheat, was intermediate after spring wheat, and was lowest following chemical fallow: 13,9 , and $1 \mathrm{pg} / \mathrm{g}$, respectively $\left(\mathrm{HSD}_{0.05}=10\right)$. When all tillage and crop treatment combinations were compared, inoculum of $F$. pseudograminearum was significantly greater after winter wheat in the noncultivated soil than after fallow in the cultivated treatment, and all other combinations contained intermediate levels of inoculum (Table 8).

A significant tillage-rotational phase interaction occurred for $\mathrm{Hel}$ gardia spp. during 2015 (Table 2), reflecting the lack of detection of this pathogen in noncultivated soil and the occurrence of large differences among rotational phases in the cultivated block. The treatment effect of rotational phase was also significant. Inoculum was greater following winter wheat than following spring wheat or chemical fallow: $288,952,56,872$, and 4,429 copies of DNA/g of soil, respectively $\left(\mathrm{HSD}_{0.05}=215,740\right)$. When all tillage and crop treatment combinations were compared for inoculum of Helgardia spp., the inoculum density was significantly greater after winter wheat than after the other two rotational phases of the cultivated treatment (Table 8), indicating the development of inoculum on winter wheat and a rapid attrition of DNA of Helgardia spp. during subsequent phases of the 3 -year rotation.

Inoculum of $R$. solani AG-8 was significantly affected only by tillage (Table 2). Inoculum was greater in noncultivated soil than in cultivated soil: 31.2 versus $0.5 \mathrm{pg} / \mathrm{g}$ of soil, respectively $\left(\mathrm{HSD}_{0.05}=3.0\right)$. When all tillage and crop treatment combinations were compared, the inoculum density in the noncultivated treatment was significantly greater after spring wheat than after winter wheat or fallow (Table 8).

Tillage-rotational phase interactions were significant for both nematode species (Table 2). For P. neglectus, there was considerably greater nematode density in noncultivated than in cultivated soil following winter wheat (12 versus 4 nematodes/g) and spring wheat (3 versus 0 nematodes/g of soil), and no difference following fallow ( 0 versus 0 nematodes/g of soil). For $P$. thornei, there was a much greater difference of nematode densities between noncultivated and cultivated treatments following spring wheat (29 versus 4 nematodes/g of soil) than following winter wheat (9 versus 4
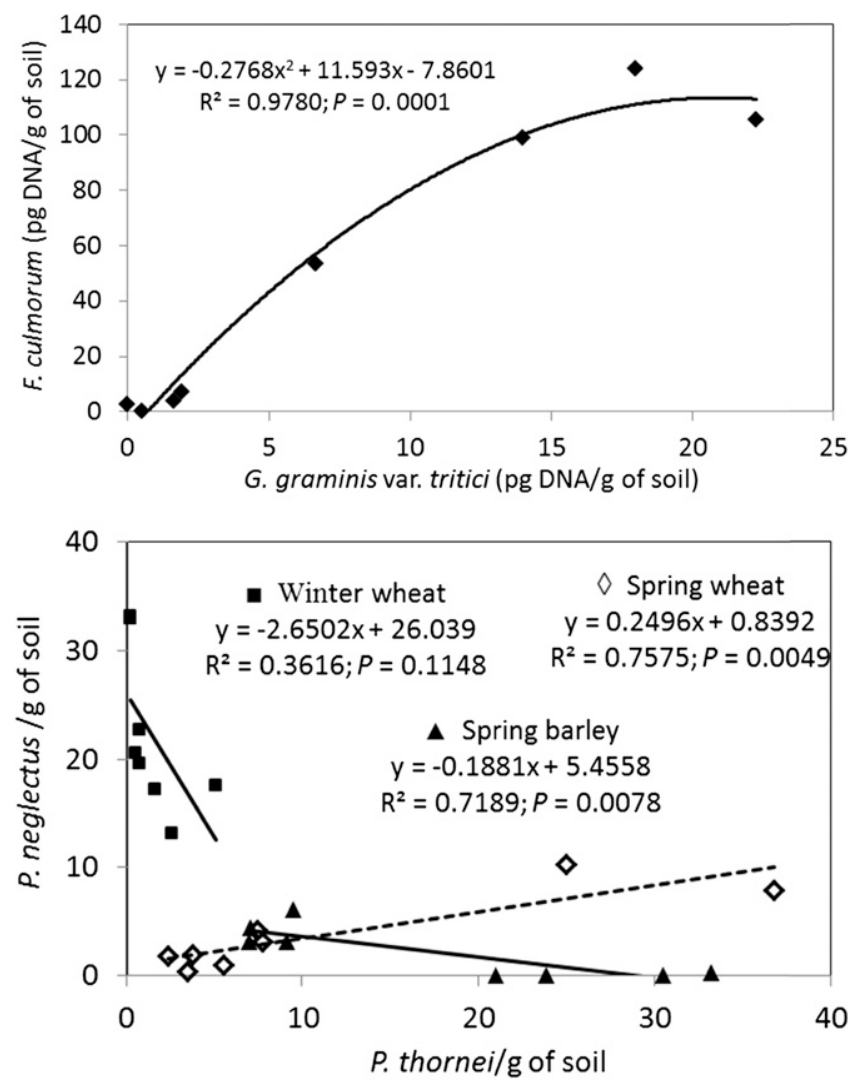

Fig. 3. Associations between the DNA concentrations of two fungal and two nematode pathogens in the annual cereals experiment (experiment 4): (top) Gaeumannomyces graminis var. tritici and Fusarium culmorum in both tillage treatments for both years of spring wheat and (bottom) Pratylenchus neglectus and P. thornei in both tillage treatments for both years of spring wheat, spring barley, and winter wheat. 
nematodes/g of soil) or fallow (7 versus 2 nematodes/g of soil). The main treatments of tillage and rotational phase were significant for both nematode species. In noncultivated compared with cultivated soils, there were 5 versus 2 nematodes/g of soil for $P$. neglectus $\left(\mathrm{HSD}_{0.05}=1\right)$ and 12 versus 6 nematodes/g of soil for $P$. thornei $\left(\mathrm{HSD}_{0.05}=4\right)$. Inoculum density of P. neglectus was significantly greater following winter wheat and spring wheat compared with fallow $(8,2$, and 0.3 nematodes/g of soil, respectively; $\left.\mathrm{HSD}_{0.05}=1\right)$. In contrast, the inoculum density of $P$. thornei was greatest following spring wheat, intermediate after winter wheat, and lowest following fallow $(12,8$, and 7 nematodes/g of soil, respectively; $\left.\mathrm{HSD}_{0.05}=4\right)$. When all tillage and crop treatment combinations were compared, the density of $P$. neglectus was significantly greater after winter wheat in the noncultivated treatment than in any other combinations of tillage and rotational phase (Table 8). For P. thornei, the density was greater after spring wheat compared with all except one other combination of tillage and rotation phase; the density after winter wheat crops
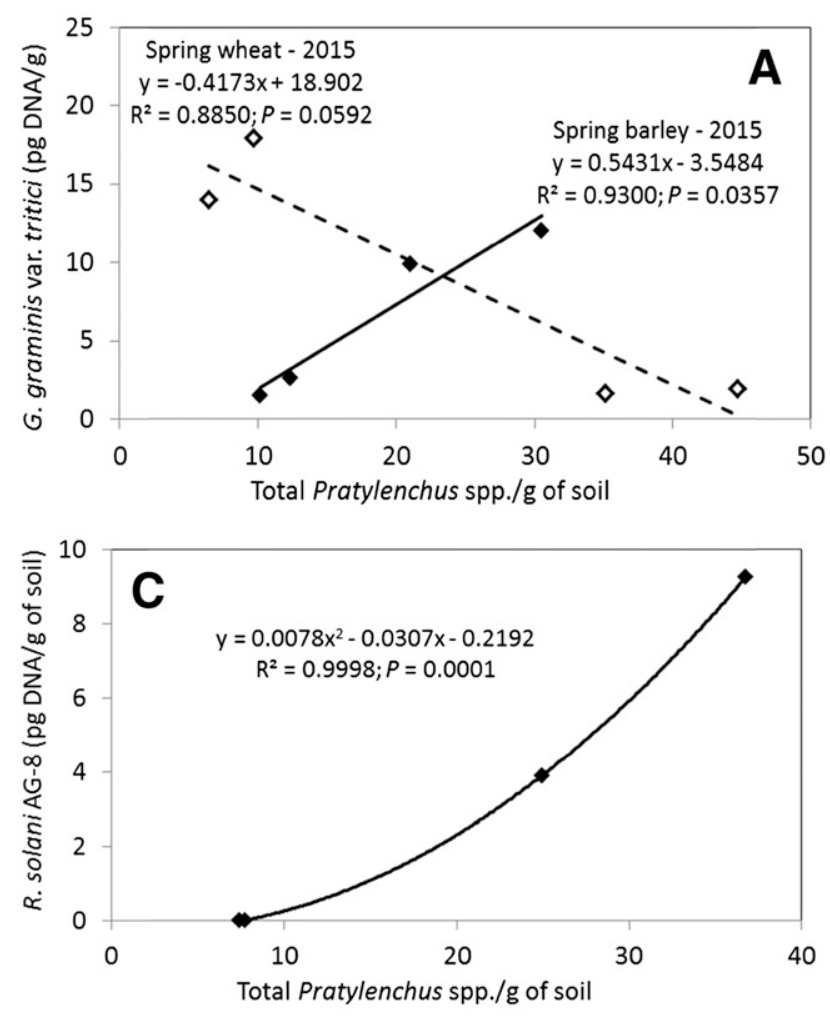

in the noncultivated treatment had intermediate densities of P. thornei (Table 8).

When all data for the experiment were grouped (two tillage and three crop treatments over 2 years; $n=24)$, there were no strong significant correlations $\left(R^{2}>0.7\right.$ and $\left.P<0.0001\right)$ between pathogens. This also occurred when data were restricted to the noncultivated tillage treatment, where strongly significant associations were detected within individual crop phases but those associations were always heavily influenced by a single outlier in the small data set $(n=4)$. A significantly positive correlation in winter wheat occurred between the density of the dominant plant-parasitic nematode $P$. thornei and the inoculum concentration of $G$. graminis var. tritici $\left(R^{2}=0.9535\right.$, $P=0.0235, n=4)$. Similar associations occurred between $P$. thornei and either $F$. culmorum or Pythium spp. clade F. However, the maximum level of significance occurred when the sum of $P$. neglectus and $P$. thornei was used for correlations with F. culmorum $\left(R^{2}=\right.$ $0.9876, P=0.0062, n=4)$ and Pythium spp. clade $\mathrm{F}\left(R^{2}=0.9483\right.$, $P=0.0262, n=4)$.




Fig. 4. Associations between the DNA concentrations of four fungal pathogens and the density of total Pratylenchus spp. (Pratylenchus neglectus plus $P$. thornei) in the annual cereals experiment (experiment 4). A, Gaeumannomyces graminis var. tritici; data are for both tillage treatments of spring barley or spring wheat during the wettest year (2015). B, Pythium spp. clade F; data are for both tillage treatments of spring wheat or spring barley during the wettest year (2015). C, Rhizoctonia solani AG-8; data are for both years of spring wheat in the no-tillage treatment. D, Bipolaris sorokiniana; data are for both tillage treatments and both years of spring wheat. E, Total Fusarium spp. (Fusarium culmorum plus F. pseudograminearum) during both years in cultivated annual spring wheat. 
Experiment 7: Organic wheat. The highest densities of $B$. sorokiniana, Pythium spp. clade F, and $R$. solani AG-8 encountered during the course of this research occurred in the organic wheat experiment (Table 3). Only one of four possible interactions among the cropping system and pulse crop mixture treatments was significant (Table 2). The interaction occurred for F. culmorum and indicated that DNA concentrations were higher in clover than in medic treatments in the cover crop system and higher in medic than clover in the intercrop system. The main effect of crop was also significant for $F$. culmorum, with more inoculum occurring in the medic than in the clover ( 3 versus $\left.2 \mathrm{pg} / \mathrm{g} ; \mathrm{HSD}_{0.05}=0.1\right)$. Pathogens for which significant main treatment differences were detected included Pythium spp. clade F, $R$. solani AG-8, and P. thornei (Table 2). Inoculum of Pythium spp. was greater in the cover crop than in the intercrop (267 versus $177 \mathrm{pg} / \mathrm{g}$ of soil; $\mathrm{HSD}_{0.05}=62$ ). In contrast, inoculum of $R$. solani was greater in the intercrop than cover crop (157 versus $28 \mathrm{pg} / \mathrm{g}$ of soil; $\mathrm{HSD}_{0.05}=109$ ). The density of $P$. thorne $i$ was greater in the cover crop than in the intercrop treatment; 11 versus 6 nematodes/g of soil, respectively $\left(\mathrm{HSD}_{0.05}=5\right)$. Phoma pinodella was also detected in this experiment (Table 3 ) and did not differ significantly among treatments $(P=0.07)$.

Preliminary sampling of this experiment during 2013 was performed using a single composite of clover plus medic samples in the cover crop and intercrop treatments. For each pathogen, the earlier sampling revealed a DNA concentration similar to that shown for these pathogens during the more comprehensive sampling during 2015 (Table 3). As during 2015, the concentration of Pythium spp. during 2013 was higher in the cover crop than the intercrop system (234 versus $176 \mathrm{pg} / \mathrm{g}$, respectively) and the opposite relationship was found for $R$. solani ( 2 versus $95 \mathrm{pg} / \mathrm{g}$ ). Samplings during both years indicated higher densities of Pratylenchus thornei than of $P$. neglectus in both management systems.

High densities of weeds occurred in the organic trial and may have influenced the dynamics of pathogen populations. During 2013, there was a uniformly high density of fiddleneck tarweed (Amsinckia lycopsoides Lehm.) and there were lower densities of prickly lettuce (Lactuca serriola L.) and Russian thistle (Salsola tragus L). During 2015 , the plot area was heavily and uniformly infested by common lambsquarters (Chenopodium berandieri Moq.) and also had lower densities of prickly lettuce and Russian thistle.

Experiment 8: Winter wheat tillage. Pathogens for which significant treatment differences were detected included $F$. culmorum, $F$. pseudograminearum, Pythium spp., $R$. solani AG-8, and $P$. thornei (Table 2). The only significant treatment interactions occurred for $R$. solani, for which the location-tillage and tillage-year interactions were significant. The location-tillage interaction reflected a greater difference in inoculum density between chemical fallows at the Pendleton and Reese sites ( 0 versus $79 \mathrm{pg} / \mathrm{g}$, respectively) than

Table 8. Influence of cereals planted into either cultivated or noncultivated 3 -year rotations on inoculum densities of five soilborne pathogens (experiment 6$)^{\mathrm{x}}$

\begin{tabular}{llcccccc}
\hline & & \multicolumn{3}{c}{ DNA (pg/g) } & & \multicolumn{2}{c}{ Nema(n/g) } \\
\cline { 3 - 4 } Tillage $^{y}$ & Phase $^{z}$ & Fp & He & Rs & & Pn & Pt \\
\hline No-till & WW & $20 \mathrm{a}$ & $0 \mathrm{~b}$ & $22 \mathrm{ab}$ & & $12 \mathrm{a}$ & $9 \mathrm{ab}$ \\
No-till & SW & $8 \mathrm{ab}$ & $0 \mathrm{~b}$ & $44 \mathrm{a}$ & $3 \mathrm{~b}$ & $19 \mathrm{a}$ \\
No-till & Fallow & $2 \mathrm{ab}$ & $0 \mathrm{~b}$ & $28 \mathrm{ab}$ & $0 \mathrm{c}$ & $7 \mathrm{~b}$ \\
Plow & WW & $10 \mathrm{ab}$ & $577,904 \mathrm{a}$ & $0 \mathrm{~b}$ & & $4 \mathrm{~b}$ & $6 \mathrm{~b}$ \\
Plow & SW & $6 \mathrm{ab}$ & $113,743 \mathrm{ab}$ & $0 \mathrm{~b}$ & & $0 \mathrm{c}$ & $4 \mathrm{~b}$ \\
Plow & Fallow & $0 \mathrm{~b}$ & $8,858 \mathrm{~b}$ & $3 \mathrm{~b}$ & & $0 \mathrm{c}$ & $8 \mathrm{~b}$ \\
\hline
\end{tabular}

${ }^{x}$ Data are 2-year means rounded to the nearest whole unit. Pathogens include Fusarium pseudograminearum (Fp), Helgardia spp. (He), Rhizoctonia solani Ag-8 (Rs), Pratylenchus neglectus (Pn), and P. thornei (Pt); and nema $=$ nematodes $(n=$ number per gram). Numbers followed by the same letter within a column are not significantly different at $P=0.05$ according to Tukey's honestly significant different test.

y Blocks were managed since 2004 either without tillage (No-till) or with inversion tillage using a moldboard plow (Plow).

${ }^{\mathrm{z}}$ Rotation phase indicates the management of the block prior to sampling; either crops of winter wheat (WW), spring wheat (SW), or fallow (Fallow). occurred between sweep treatments at those locations ( 5 versus $20 \mathrm{pg} / \mathrm{g}$, respectively). The tillage-year interaction reflected a greater difference in inoculum density between chemical fallows during 2013 and 2015 (27 versus 64 pg/g, respectively) than occurred between sweep treatments during those years (16 versus $10 \mathrm{pg} / \mathrm{g}$, respectively). Significant main treatment effects of location and tillage also occurred for $R$. solani. The effect of location indicated that inoculum concentration was greater at the Reese site than at Pendleton: 50 versus $3 \mathrm{pg} / \mathrm{g}$, respectively $\left(\mathrm{HSD}_{0.05}=20\right)$. The inoculum density was also higher in chemical fallow compared with cultivated fallow (46 versus $13 \mathrm{pg} / \mathrm{g} ; \mathrm{HSD}_{0.05}=20$ ). The latter effect occurred in response to a strong difference at the Reese site but not at the Pendleton site (Table 9). When all tillage and crop treatment combinations were compared for inoculum of $R$. solani AG-8, the inoculum density was significantly greater in the no-till system at the Reese site than for all other combinations of location and tillage system (Table 9).

For F. culmorum, the significant main treatment effect for location (Table 2) indicated that, whereas inoculum was greater at Pendleton than at the Reese site ( 2 versus $\left.0 \mathrm{pg} / \mathrm{g} ; \mathrm{HSD}_{0.05}=2\right)$, the actual concentrations for F. culmorum were very low at both sites. In contrast, inoculum of $F$. pseudograminearum was higher at the Reese site than at Pendleton ( 13 versus $3 \mathrm{pg} / \mathrm{g} ; \mathrm{HSD}_{0.05}=6$ ). A significant treatment effect for tillage indicated that the density of $F$. pseudograminearum was higher in the cultivated fallow compared with the chemical fallow $\left(12\right.$ versus $\left.5 \mathrm{pg} / \mathrm{g} ; \mathrm{HSD}_{0.05}=2\right)$. When all tillage and crop treatment combinations were compared for inoculum of $F$. culmorum, the inoculum density was significantly greater in the sweep tillage system at Pendleton than for all other combinations of location and tillage system (Table 9). In contrast, inoculum density of $F$. pseudograminearum was greater in the sweep tillage system at the Reese site than for all other combinations of location and tillage system (Table 9).

For Pythium spp., a significant treatment effect of year (Table 2) indicated that there was a slightly higher inoculum density during 2013 compared with 2015 (24 versus $18 \mathrm{pg} / \mathrm{g} ; \mathrm{HSD}_{0.05}=5$ ). However, there were no differences in inoculum density for Pythium spp. among any combination of locations and tillage systems (Table 9).The significant effect of location for $P$. thornei (Table 2) indicated that the inoculum density was greater at Pendleton than at the Reese site: 0.7 versus 0.1 nematodes/g of soil $\left(\mathrm{HSD}_{0.05}=0.2\right)$. However, the density of nematodes at each location and in each tillage system was considered too low to have been of biological importance. There were no strongly significant correlations among pathogens in this experiment.

\section{Discussion}

This DNA-based survey provided unique insights into the effect of sustained crop management systems on communities of soilborne

Table 9. Influence of cereals planted into either cultivated or noncultivated rotations of winter wheat and fallow at two locations on inoculum densities of five soilborne pathogens (experiment 8$)^{\mathrm{x}}$

\begin{tabular}{lllrrrr}
\hline & & \multicolumn{4}{c}{ DNA (pg/g) } & \\
\cline { 3 - 5 } Tillagey $^{n}$ & Location $^{z}$ & Fc & Fp & Py & Rs & Pt (n/g) \\
\hline No-till & Pendleton & $1 \mathrm{ab}$ & $1 \mathrm{~b}$ & $18 \mathrm{a}$ & $0 \mathrm{~b}$ & $0.7 \mathrm{a}$ \\
Sweep & Pendleton & $3 \mathrm{a}$ & $5 \mathrm{~b}$ & $24 \mathrm{a}$ & $5 \mathrm{~b}$ & $0.8 \mathrm{a}$ \\
No-till & Reese & $0 \mathrm{~b}$ & $8 \mathrm{~b}$ & $22 \mathrm{a}$ & $79 \mathrm{a}$ & $0.0 \mathrm{~b}$ \\
Sweep & Reese & $0 \mathrm{~b}$ & $19 \mathrm{a}$ & $20 \mathrm{a}$ & $20 \mathrm{~b}$ & $0.1 \mathrm{~b}$ \\
\hline
\end{tabular}

${ }^{x}$ Data are 2-year means rounded to the nearest whole unit. Pathogens include Fusarium culmorum (Fc), Fusarium pseudograminearum (Fp), Pythium spp. clade F (Py), Rhizoctonia solani AG-8 (Rs), and Pratylenchus thornei (Pt; $n=$ number of nematodes per gram). Numbers followed by the same letter within a column are not significantly different at $P=0.05$ according to Tukey's honestly significant different test.

y Blocks were managed since 2002 either without tillage (No-till) or with minimum tillage using a subsurface sweep plow (Sweep).

${ }^{\mathrm{z}}$ Locations were the United States Department of Agriculture-Agricultural Research Center northeast of Pendleton, OR (Pendleton) and the Reese site west of Pendleton (Reese). 
pathogens. The density of inoculum for a broad group of pathogens in these stabilized ecosystems could not have been uniformly identified in any other way. Results of this survey will provide guidance for subsequent research on pathogen dynamics and root disease complexes in semiarid temperate climates.

As anticipated, several findings differed from those reported for shorter-term experiments in which ecosystems were in a state of transition following changes from one farming practice to another (Paulitz et al. 2010; Schroeder and Paulitz 2006). Likewise, the relative densities of inocula for some pathogens were sometimes poorly related to previous observations of root diseases in these experiments (Smiley et al. 1996a). Paulitz et al. (2010) also reported poor relationships between pathogen inoculum density and incidence or severity of root diseases of wheat in the PNW. The diseases caused by the soilborne pathogens in these experiments are strongly affected by environmental conditions (Okubara et al. 2014; Paulitz et al. 2010; Poole et al. 2013, 2015; Smiley 2009a; Smiley et al. 1996a). In view of the different precipitation patterns that occurred over 2 years of this study, we anticipated that the main treatment effect for year would have been significant for far more than the $9 \%$ of cross-year comparisons detected in these apparently well-stabilized long-term experiments.

The sampling intensity was very high for this survey (12 to 1,000 cores/ha). The combination of high-density sampling and extraction of DNA from the entire 400- to 500-g sample was presumed to be sufficient to minimize variability, which is thought to be much higher with low sampling intensities and extraction of DNA from $0.5 \mathrm{~g}$ or less of each composite sample (Okubara et al. 2008, 2015; Schroeder and Paulitz 2006; Yan et al. 2012).

Pathogen inoculum densities reported by the PreDicta B assay have been associated with risks of potential yield reductions from diseases in Australia (McKay et al. 2008). We could not directly apply the risk assessments because the disease process for each pathogen would be expected to differ in response to differences in soils, climates, and agronomic practices between Australia and the PNW. Also, our sampling procedure differed from that which was used to establish the PreDicta B's DNA-by-disease risk associations. Samples in Australia were taken to a depth of $10 \mathrm{~cm}$ (Evans and McKay 2012; McKay et al. 2008; Poole et al. 2015) and our samples were taken to a depth of $20 \mathrm{~cm}$ based upon our knowledge of the vertical distribution of Pratylenchus spp. in the silt loams we evaluated (Smiley et al. 2008). Because the upper $12 \mathrm{~cm}$ is the zone of highest concentration of inoculum for the fungal pathogens but not for rootlesion nematodes in the fields we studied (R. W. Smiley, unpublished) (Smiley et al. 2008), our sampling method presumably diluted the apparent peak DNA concentrations of fungal inocula in the upper profile. Nevertheless, the DNA concentrations reported for pathogens in this study were comparable with those reported for shallower samples in Australia (Poole et al. 2015) and in the PNW (Okubara et al. 2014; Paulitz et al. 2010).

The DNA assay used for this study provided important information regarding the complexity of pathogen dynamics occurring in multiple stabile ecosystems at a single location. That the ecosystems are relatively stable was indicated by a relative scarcity of significant differences across two sampling years that had important differences in rainfall amounts and distributions before our soil samples were collected. Key findings specific to individual pathogens are discussed below.

B. sorokiniana. Common root rot was not detected during the previous survey of diseases in these long-term experiments (Smiley et al. 1996a). Inoculum of B. sorokiniana in this study was not detected in any experiment in which winter wheat was the only small grain crop produced (experiments 1, 2,3, and 8). This pathogen was also not detected in the 3-year rotation of winter wheat, spring wheat, and fallow (experiment 6). Inoculum of B. sorokiniana was found at sometimes high densities in experiments where spring cereals were the only small grain crop: the annual spring wheat (experiment 4) and the organic spring wheat (experiment 7). In the annual spring cereals plantings, the inoculum density was greater in spring wheat than in spring barley. Because more than $90 \%$ of wheat produced in Oregon is winter wheat, these results help to explain why common root rot is currently a minor component of the crown and root disease complex in the PNW (Smiley and Patterson 1996) compared with other geographic regions in which spring wheat is the dominant crop (Bockus et al. 2010; Smiley et al. 2009).

D. tritici-repentis. The tan spot pathogen was previously not known to be present in the long-term experiments at Pendleton. During 2015, this pathogen was detected in three experiments: the conservation-tillage treatment of the wheat-pea rotation (experiment 3 ), the no-till annual spring wheat (experiment 4), and the perennial grass pasture (experiment 5). This detection was important in that it appears to be the first formal report of $D$. tritici-repentis in the region of eastern Oregon where these experiments are located, and where agriculture is transitioning to more sustainable cropping systems that retain greater amounts of cereal stubble above the soil surface. Stubble-retention systems are known to favor an increasing incidence and severity of tan spot (De Wolf et al. 1998). A heightened awareness of tan spot is warranted in the semiarid wheat-producing region of the PNW.

F. culmorum and $\boldsymbol{F}$. pseudograminearum. Crown rot is widespread and is economically important throughout the PNW (Cook 1981; Poole et al. 2013; Smiley 2009a; Smiley and Patterson 1996; Smiley et al. 1996a, 2013b). Substantial concentrations of DNA of Fusarium spp. were detected in four experiments, with $F$. culmorum being the dominant species in experiment 4 (annual cereals) and $F$. pseudograminearum being the dominant specie in experiment 5 (pasture versus wheat), experiment 6 (3-year rotation), and experiment 8 (winter wheat tillage). In the annual cereals experiment, there were strong tillage-crop interactions; inoculum of $F$. culmorum was high only in cultivated annual spring wheat and in no-till annual spring barley, and inoculum of $F$. pseudograminearum was high only in cultivated annual winter wheat. We previously reported similar findings from another long-term experiment where $F$. pseudograminearum was dominant in a winter wheat-cultivated fallow sequence and in no-till annual winter wheat, whereas a more balanced density of $F$. pseudograminearum and $F$. culmorum occurred in no-till annual spring wheat, no-till annual spring barley, and in a 3-year no-till rotation of winter wheat, spring barley, and chemical fallow (Smiley et al. 2013b). Supportive evidence for the selective process for these species occurred in the 3-year rotation (experiment 6), where the concentration of $F$. pseudograminearum was higher following winter wheat than spring wheat, with the density declining to very low concentrations during the fallow phase. There were no treatment effects on $F$. culmorum in that experiment. It appears that winter wheat and spring cereals are exerting a selective influence on the dominances of Fusarium spp., which adds complexity to climatic variables that also influence the incidence and severity of crown rot in the PNW (Poole et al. 2013; Smiley 2009a).

In the comparison with fallow management practices with the same winter wheat cultivar (Bobtail) at two locations (experiment 8), we detected more F. culmorum at the cooler, wetter site (Pendleton) and more $F$. pseudograminearum at the warmer, drier site (Reese), supporting previous observations regarding effects of climate on these species (Cook 1968; Poole et al. 2013; Smiley and Patterson 1996). At the Reese site, the concentration of $F$. pseudograminearum was higher in the cultivated fallow compared with no-till fallow. Because the greatest amount of inoculum for these Fusarium spp. occurs in lower culm tissue (Evans et al. 2012; Hogg et al. 2010), it is possible that, in our samplings, a smaller proportion of stem tissue may have been sampled in no-till systems compared with samplings from soils in which tillage had buried inoculumbearing stem tissue during previous crop years. These Fusarium spp. persist very well in buried straw (Evans 2012).

We did not anticipate detection of both Fusarium spp. at only very low concentrations in three of the eight experiments (experiments 2, 3 , and 7). It is not known why such low values occurred in a region where crown rot is common. The low values were unlikely to have been a response to repeated plantings of the small grain cultivars used in these experiments because the spring wheat and winter wheat cultivars in these experiments are each known to be susceptible to Fusarium crown rot, although specific differential responses to $F$. culmorum versus F. pseudograminearum have not been investigated. Also, a low 
detection level of Fusarium spp. in the five experiments was unlikely to have been due to an inability to detect one or both of these species using the PreDicta B analysis, as shown by the detection of both species at relatively high inoculum densities in certain treatments of five experiments (experiments 1, 4, 5, 6, and 8). For the tillage-fertility experiment (experiment 2), increasing densities of F. culmorum coincided with increasing rates of $\mathrm{N}$ application, corresponding to a similar trend for expression of whiteheads caused by crown rot (Smiley et al. 1996a). However, presumably because the inoculum concentrations were too low, we did not measure differences of Fusarium spp. among tillage treatments, which contrasted with observations of a direct relationship between increasing amounts of surface residue and damage by crown rot (Smiley et al. 1996a; Summerell et al. 1989).

G. graminis var. tritici. Inoculum of the take-all pathogen differed among treatments in five of eight experiments. In the annual cereals experiment (experiment 4), significantly higher inoculum densities were detected in cultivated than in the noncultivated cropping systems. This is in contrast to the development of greater take-all disease in no-till than cultivated soil in eastern Washington (Cook et al. 2002; Moore and Cook 1984; Paulitz et al. 2002) but is consistent with other reports of tillage effects on take-all (Folwell et al. 1991; Schroeder and Paulitz 2006; Yarham 1981). We also noted that the greatest inoculum density occurred in cultivated winter wheat compared with cultivated spring wheat or spring barley. Our samples were collected directly in the rows during early spring before spring crop subplots had been plowed prior to planting, and when winter wheat subplots had been plowed and planted 4 to 5 months earlier. Inoculum of $G$. graminis var. tritici could have become amplified on winter wheat subjected to slow growth rates during winter, causing apparent differences that might not have been detected if all soils were sampled at the same plant growth stage or following harvest. In the noncultivated treatment of the annual cereals block, we detected very little G. graminis var. tritici when samples were collected following wheat and barley planted annually for 18 years. Additional study is warranted to determine whether take-all decline (Shipton 1975) has become established in the no-till annual cereals block.

In the fertility management experiment (experiment 1), the inoculum density was either nondetectable or low in all except one treatment, the stubble burning treatment ( $90 \mathrm{~N}+$ burn) following the wheat phase of the rotation. That burn treatment was previously noted for a low microbial diversity and low concentrations of organic C and N (Collins et al. 1992; Rasmussen and Smiley 1996). The takeall pathogen was not detectable following the fallow phase of that treatment. During an earlier disease survey (Smiley et al. 1996a), take-all became damaging in only that same treatment, the 90 $\mathrm{N}+$ burn. Removal of stubble by burning typically does not enhance or suppress the incidence or severity of take-all in short-term experiments (Shipton 1975; Yarham 1981). We previously speculated (Smiley et al. 1996a) that modification of the microbial biomass and the soil chemical and physical qualities of soil by repetitive burning may have resulted in microbe-host-parasite interactions quite different from those in short-term investigations. The inoculum density data reported here support the hypothesis that the pathogen is capable of rapidly colonizing wheat roots due to low levels of microbial competition or antagonism in this stubble-burn treatment, providing the pathogen a greater opportunity for increasing its inoculum density during each wheat cycle, compared with treatments where stubble is retained and soil organic constituents and microbial diversity are more robust. These relationships warrant further investigation.

We found low concentrations of G. graminis var. tritici inoculum in a pasture established during 1931, providing supportive evidence that grasslands in the semiarid PNW support the survival of this pathogen and can potentially provide inoculum when grasslands are converted into crop production. This has been an especially important problem when former semiarid grasslands were converted to production of irrigated small grains, in which take-all then became common and particularly severe (Cook et al. 1968).

Helgardia spp. The eyespot pathogens that include Helgardia acuformis and $H$. herpotrichoides are also known as Oculimacula acuformis and O. yallundae, respectively (Murray 2010). Both pathogens occur mostly on winter wheat in the PNW (Dyer et al. 2001; Murray 2010). In this research, the pathogen inoculum concentrations were evaluated on the same winter wheat experiments in which we used visual symptoms to evaluate eyespot incidence and severity two decades earlier (Smiley et al. 1996a). In the present survey, we found that the pathogen was detected in but did not differ among treatments in any experiment in which winter wheat was the only cereal produced either during alternate years (experiments $1,2,3$, and 8 ) or annually (experiment 5). We did not detect the pathogen in any of the annual winter wheat treatments (experiments 4 and 5). In experiment 6 , we detected the pathogen in the pasture but not in the no-till winter wheat. The 3-year rotation (experiment 6) was the only trial in which inoculum density of Helgardia spp. differed among treatments: none was detected in any phase of the no-till block, and inoculum was high following winter wheat in the cultivated block and diminished greatly each year during the spring wheat and chemical fallow phases of the rotation. The winter wheat cultivars we planted were either moderately resistant (ORCF 102; experiments 1 to 7) or susceptible (Bobtail; experiment 8) to eyespot. Potential biological antagonisms against Helgardia spp. should be examined to determine why these species were not detected in any of these annual wheat plantings. This research also provided evidence that at least some grasslands can serve as a localized source of inoculum for these pathogens.

Phoma pinodella. This seed- and residue-borne, soil-persistent pathogen was detected only in plots treated with pea vines in the fertility management experiment (experiment 1), in all treatments of the wheat-pea rotation (experiment 3), and in the organic spring wheat experiment that includes intercrops or cover crops of clover and medic (experiment 7). In the wheat-pea rotation, inoculum levels were higher following pea than wheat, were higher under conservation tillage than inversion tillage, and were highest during the wettest year. These principles are well established (Bretag and Ramsey 2001) but this pathogen, which is a component of the fungal complex causing Ascochyta blight, was not previously known to be a component of the legume foot rot complex at the experimental site. Likewise, in a similar survey of pathogen DNA at a much lower rainfall site in Oregon (Smiley et al. 2013b), Phoma pinodella was detected only in a winter wheat-winter pea rotation. Research is needed to determine whether this pathogen limits production of pulse crops in semiarid regions of the PNW.

Pratylenchus neglectus and $\boldsymbol{P}$. thornei. Effects of root-lesion nematodes on small grain cereals have been studied intensively in the PNW during the past decade (Smiley and Nicol 2009; Smiley et al. 2004, 2013a). One or both species of these Pratylenchus spp. were detected in high densities in all eight experiments (e.g., >2 nematodes/g of soil). Differences in nematode density occurred among treatments in each experiment, except the comparison of pasture versus no-till winter wheat. Inoculum densities for Pratylenchus neglectus, $P$. thornei, or both, were sufficient to indicate a potential risk for reduced wheat yields in at least some treatments of all eight experiments. We recently reported inverse relationships between Pratylenchus spp. density and yield of wheat (Smiley 2009b; Smiley and Machado 2009; Smiley et al. 2004, 2005a,b). We also reported a reduced capacity of wheat roots to extract water from the soil profile in plots with the highest densities of P. neglectus (Smiley and Machado 2009), and a high correlation between densities of Pratylenchus spp. assayed by qPCR and by traditional extraction and identification methods (Smiley et al. 2013a). These results reemphasize that Pratylenchus spp. must be considered among important diseases that influence yields of wheat and other crops in low-rainfall environments (Smiley et al. 2014b).

Results from the current survey supported our previous observations that $P$. neglectus is favored by winter wheat and $P$. thornei is favored by spring wheat (Smiley et al. 2013a, 2014a). P. neglectus was dominant over $P$. thorne $i$ in the annual winter wheat, in the cultivated winter wheat-spring pea rotation, and in the fertility management and tillage-fertility experiments. $P$. thorne $i$ was dominant in the spring wheat and spring barley subplots of the annual cereals experiments and in the organic wheat experiment which is planted to 
spring wheat and pulse crops. Our findings from long-term experiments in two contrasting precipitation zones provide potential explanations for reports from adjacent farms in southeast Idaho, which have dominance of either $P$. neglectus or $P$. thornei, with the only known difference being that one farm produces only winter wheat and the other farm produces only spring wheat (R. W. Smiley, unreported communications with wheat producers). This aspect of Pratylenchus spp. management requires greater investigation to minimize the level of risk because wheat cultivars differ in resistance as well as tolerance to these two Pratylenchus spp. (Smiley and Nicol 2009; Thompson et al. 2008; Vanstone et al. 2008). This also underscores the importance of developing cultivars with dual-species resistance (Thompson et al. 2015) and, until that is accomplished, of developing species-specific diagnostic methods (Yan et al. 2012, 2013) for use in nematode diagnostic laboratories. Likewise, it is important to determine the mechanisms of this species-specific selection pressure by cultivars of wheat and other field crops (Smiley et al. 2014b).

Pythium spp. (clade F). Without treatment of planted seed with an appropriate fungicide, Pythium seed rot, seedling damping-off, and root rot occur widely across the low-precipitation regions of the PNW (Chamswarng and Cook 1985; Ingram and Cook 1990; Paulitz et al. 2002; Smiley et al. 1996b). Therefore, nearly all wheat seed in the PNW is treated with either metalaxyl or mefenoxam to suppress the seed and seedling phases of Pythium diseases (Smiley et al. 1996b). Species within clade F (LéVesque and De Cock 2004) that are pathogenic to small grains and known to be present in the PNW include Pythium appressorium, $P$. debaryanum, $P$. intermedium, $P$. irregulare, $P$. paroecandrum, and $P$. sylvaticum (Higginbotham et al. 2004; Paulitz and Adams 2003; Schroeder et al. 2006). High concentrations of DNA of Pythium spp. clade F were detected in at least some treatments of most experiments, and concentrations were influenced by one or more treatments or interactions in six of eight experiments.

In the fertility management experiment (experiment 1 ), the inoculum density in the fallow which followed winter wheat was higher in the manure and pea vine treatments than in other treatments. However, the density became essentially equal in all treatments when seedling winter wheat was sampled following the 14-month cultivated fallow. Cook et al. (1987) reported that burning straw in a wheatfallow rotation reduced inoculum density of Pythium spp. and increased wheat plant growth. A reduced microbial biomass and a less diverse microbial composition in long-term burn treatments (Collins et al. 1992) may have favored activity of Pythium spp. in a manner that negated advantages gained by reducing the Pythium population when straw is burned in shorter-term experiments.

It has been reported that inoculum density of Pythium spp. was comparable among tillage systems in shorter-term experiments (Cook et al. 1990; Schroeder and Paulitz 2006). In the tillage-fertility experiment (experiment 2), the inoculum density was higher at the lowest $\mathrm{N}$ application rates and in the tillage treatments having the highest amount of surface residue. Soil acidification due to application of $\mathrm{N}$ fertilizer in this experiment is more intense in the higher than in the lower $\mathrm{N}$ treatments, and organic $\mathrm{C}$ and $\mathrm{N}$ are greater in the soils where acidification is most intense (Rasmussen and Smiley 1994). Associations between Pythium inoculum density and soil chemical and microbial properties should be investigated.

R. solani AG-8. Rhizoctonia root rot occurs throughout the lowrainfall regions of the PNW (Okubara et al. 2014; Paulitz et al. 2002; Smiley et al. 2009). Inoculum of this pathogen differed significantly among treatments or interactions in five of eight experiments. Inoculum occurred at low concentrations in three experiments (experiments 1,2 , and 8 ), where winter wheat was alternated with a 14-month fallow period. In experiment 8 , the inoculum density was greater in the chemical fallow than the cultivated fallow in the winter wheat-fallow rotation at the Reese site. In contrast, inoculum was much greater in the plow than in the conservation treatment of the winter wheat-spring pea rotation (experiment 3) at Pendleton. It is generally recognized that Rhizoctonia root rot becomes more damaging in noncultivated than in cultivated cereals (Paulitz et al. 2002; Smiley et al. 2009). In shorter-term studies, this disease typically also becomes more pronounced with successive cereal crops (Schroeder and Paulitz 2006) but, at some point, begins to become moderated through a disease decline phenomenon presumed to involve microbial processes. In this study, the effect of tillage was particularly pronounced in experiments 6 and 8 . In experiment 6 , at Pendleton, the inoculum concentration was high in the noncultivated treatment and was barely detectable in the cultivated treatment. A similar pattern occurred at the Reese site in experiment 8 , where the inoculum concentration was high in the no-till treatment and much lower in the sweep-tillage treatment. The inoculum concentrations detected particularly in noncultivated soils in this study were within the range reported for severely affected fields in the region (Okubara et al. 2008). In experiment 6 , we also detected an increasing inoculum density during the two successive years of wheat in the 3-year rotation of winter wheat-spring wheat-chemical fallow. The main treatment effect for year was significant for $R$. solani AG-8 in only one experiment (experiment 5). In that experiment, the concentration of DNA was much greater during the wetter (2015) than the drier (2013) year, which is contrary to reports by Okubara et al. (2015) and Poole et al. (2015).

A lack of direct relationship between inoculum concentration and disease occurrence in noncultivated soils has been reported (Paulitz et al. 2010). Okubara et al. (2015) found no relationship between tillage and the concentration of DNA for $R$. solani AG-8, although saprophytic growth and survival of $R$. solani AG-8 in soil have been shown to be reduced by tillage (Gill et al. 2001; Rovira 1986). Our previous assays of diseases in these experiments showed that Rhizoctonia root rot incidence and severity in the wheat-pea rotation were unaffected by tillage (Smiley et al. 1996a) and that the microbial biomass in those treatments was inversely correlated with incidence and severity of Rhizoctonia root rot. In the present survey, we also found that the DNA concentration of $R$. solani AG- 8 was much greater following the wheat than the pea phase of the winter wheat-pea rotation. Okubara et al. (2015) also reported that inoculum density of this pathogen was greatly reduced following growth of all broadleaf crops. Complex interactions between suppressive microbes and $R$. solani AG- 8 are likely to have a strong influence on both inoculum density and disease occurrence, and these relationships warrant comprehensive evaluation as cropping systems in the PNW evolve toward more sustainable production systems.

Interactions of pathogens. Castillo and Vovlas (2007) summarized reports of interactions between Pratylenchus spp. and either $R$. solani or G. graminis var. tritici. Occurrences of important interactions between Pratylenchus thornei and either F. culmorum or $F$. pseudograminearum were recently reported (Hajihassani et al. 2013; Simpfendorfer et al. 2012). We illustrated a positive interaction between Pratylenchus spp. and F. culmorum $+F$. pseudograminearum, and between Pratylenchus spp. and R. solani AG-8 (Fig. 4). We also detected a negative association between Pratylenchus spp. and $B$. sorokiniana, and both positive and negative associations between Pratylenchus spp. and G. graminis var. tritici and between Pratylenchus spp. and Pythium spp. clade F (Fig. 4). Poole et al. (2015) also evaluated pathogen DNA in soil and the associated climatic conditions over time to provide evidence of competitive interactions among soilborne plant pathogens. Roberts and Sivasithamparam (1987) suggested that combinations of fungal pathogens may be more associated with the expression of symptoms of Rhizoctonia root rot than the effects of $R$. solani AG-8 acting alone. We detected a positive association between $F$. culmorum and G. graminis var. tritici, and both positive and negative associations between $P$. neglectus and P. thornei (Fig. 3). A greater understanding of interactions among these soilborne pathogens and among soil ecosystems is imperative for improving holistic management practices for diseases of field crops in the PNW.

Conclusion. Results of this survey illustrated that influences of cropping systems on densities of fungal and nematode pathogens are complex and still poorly understood. Recent use of qPCR to evaluate pathogen inoculum densities in the PNW soils (Paulitz et al. 2010; Smiley et al. 2013a,b) have begun to reveal many new findings that will provide additional guidance for research aimed at improving the efficiency of crop production. The comparative uniformity of 
Pythium and Rhizoctonia inoculum levels we detected among various tillage and cropping systems was reported previously in areas of higher precipitation or irrigated agriculture (Paulitz et al. 2010; Schroeder and Paulitz 2006) and also in areas of low precipitation (Smiley et al. 2013b). The pathogen Phoma pinodella warrants further scrutiny as a previously unsuspected component of the disease complex of food legume crops in semiarid regions of the PNW. Further observations are justified to determine whether this pathogen restricts yields of food legume crops in the PNW. Likewise, detection of the previously unreported tan spot pathogen, D. tritici-repentis, provides reason to be alert for establishment of this pathogen in wheat-producing areas of the semiarid PNW. We provided additional evidence that winter wheat and spring crops exert differential selection pressures on populations of Fusarium spp. and Pratylenchus spp. Associations between fungal pathogens and between fungal pathogens and plant-parasitic nematode species must also be evaluated more fully in future research.

\section{Acknowledgments}

Funding was provided by the Oregon State University Agricultural Research Foundation, Oregon Agricultural Experiment Station, United States Department of Agriculture-Agricultural Research Service, and a discounted analysis fee by the Root Disease Testing Service of the South Australian Research and Development Institute. Sampling assistance was contributed by J. Gourlie, M. Chandler, M. Baxter, G. Yan, L. Pritchett, A. Spence, E. Torres, and M. Wuest.

\section{Literature Cited}

Bentley, A. R., Leslie, J. F., Liew, E. C. Y., Burgess, L. W., and Summerell, B. A. 2008. Genetic structure of Fusarium pseudograminearum populations from the Australian grain belt. Phytopathology 98:250-255.

Bithell, S. L., McKay, A., Butler, R. C., Herdina, Ophel-Keller, K., Hartley, D., and Cromey, M. G. 2012. Predicting take-all severity in second-year wheat using soil DNA concentrations of Gaeumannomyces graminis var. tritici determined with qPCR. Plant Dis. 96:443-451.

Bockus, W. W., Bowden, R. L., Hunger, R. M., Morrill, W. L., Murray, T. D., and Smiley, R. W., eds. 2010. Compendium of Wheat Diseases and Pests, 3rd ed. American Phytopathological Society, St. Paul, MN.

Bretag, T. W., and Ramsey, M. 2001. Foliar diseases caused by fungi: Ascochyta spp. Pages 24-28 in: Compendium of Pea Diseases, 2nd ed. J. M. Kraft and F. L. Pfleger, eds. American Phytopathological Society, St. Paul, MN.

Castillo, P., and Vovlas, N. 2007. Pratylenchus (Nematoda, Pratylenchidae): Diagnosis, Biology, Pathogenicity and Management. American Phytopathological Society, St. Paul, MN.

Chamswarng, C., and Cook, R. J. 1985. Identification and comparative pathogenicity of Pythium species from wheat roots and wheat-field soils in the Pacific Northwest. Phytopathology 75:821-827.

Collins, H. C., Rasmussen, P. E., and Douglas, C. L., Jr. 1992. Crop residue management effects on soil carbon and microbial dynamics. Soil Sci. Soc. Am. J. 56:783-788.

Cook, R. J. 1968. Fusarium root and foot rot of cereals in the Pacific Northwest. Phytopathology 58:127-131.

Cook, R. J. 1981. Fusarium diseases of wheat and other small grains in North America. Pages 39-52 in: Fusarium: Diseases, Biology, and Taxonomy. P. E. Nelson, T. A. Toussoun, and R. J. Cook, eds. The Pennsylvania State University Press, University Park.

Cook, R. J., Chamswarng, C., and Tang, W. H. 1990. Influence of wheat chaff and tillage on Pythium populations in soil and Pythium damage to wheat. Soil Biol. Biochem. 22:939-947.

Cook, R. J., Huber, D., Powelson, R. L., and Bruehl, G. W. 1968. Occurrence of take-all in wheat in the Pacific Northwest. Plant Dis. Rep. 52:716-718.

Cook, R. J., Schillinger, W. F., and Christensen, N. W. 2002. Rhizoctonia root rot and take-all of wheat in diverse direct-seed spring cropping systems. Can. J. Plant Pathol. 24:349-358.

Cook, R. J., Sitton, J. W., and Haglund, W. A. 1987. Influence of soil treatments on growth and yield of wheat and implications for control of Pythium root rot. Phytopathology 77:1192-1198.

De Wolf, E. D., Effertz, R. J., Ali, S., and Francl, L. J. 1998. Vistas of tan spot research. Can. J. Plant Pathol. 20:349-370.

Duff, B., Rasmussen, P. E., and Smiley, R. W. 1995. Wheat/fallow systems in the semi-arid regions of Pacific NW America. Pages 85-111 in: Agricultural Sustainability: Economic, Environmental and Statistical Considerations. V. Barnett, R. Payne, and R. Steiner, eds. John Wiley \& Sons, London.

Dyer, P. S., Furneaux, P. A., Douhan, G., and Murray, T. D. 2001. A multiplex PCR test for determination of mating type applied to the plant pathogens Tapesia yallundae and Tapesia acuformis. Fungal Genet. Biol. 33:173-180.

Evans, M. L. 2012. Changes in Fusarium pseudograminearum DNA concentrations in cereal residues and soil over summer and autumn. Page 28 in: Proc. First Int. Crown
Rot Workshop, Narrabri, New South Wales, Australia. R. I. S. Brettell and J. M. Nicol, eds. Grains Research and Development Corp., Canberra, Australia.

Evans, M. L., and McKay, A. 2012. Quantitative polymerase chain reaction as a tool in field research. Page 78 in: Proc. First Int. Crown Rot Workshop, Narrabri, New South Wales, Australia. R. I. S. Brettell and J. M. Nicol, eds. Grains Research and Development Corp., Canberra, Australia.

Evans, M. L., Wallwork, H., and Naglis, G. 2012. Vertical distribution of Fusarium pseudograminearum and $F$. culmorum DNA in cereal plants. Page 29 in: Proc. First Int. Crown Rot Workshop, Narrabri, New South Wales, Australia. R. I. S. Brettell and J. M. Nicol, eds. Grains Research and Development Corp., Canberra, Australia.

Folwell, R. J., Cook, R. J., Heim, M. N., and Moore, D. L. 1991. Economic significance of take-all on winter wheat in the Pacific Northwest USA. Crop Prot. 10:391-395

Gill, J. S., Sivasithamparam, K., and Smettem, K. R. J. 2001. Influence of depth of soil disturbance on root growth dynamics of wheat seedlings associated with Rhizoctonia solani AG-8 disease severity in sandy and loamy soils of Western Australia. Soil Tillage Res. 62:73-83.

Hajihassani, A., Smiley, R. W., and Afshar, F. J. 2013. Effects of co-inoculations with Pratylenchus thornei and Fusarium culmorum on growth and yield of winter wheat. Plant Dis. 97:1470-1477.

Higginbotham, R. W., Paulitz, T. C., and Kidwell, K. K. 2004. Virulence of Pythium species isolated from wheat fields in eastern Washington. Plant Dis. 88:1021-1026.

Hogg, A. C., Kephart, K. D., Dyer, A. T., Klouser, L., Johnston, R. H., and Johnston, J. A. 2010. Monitoring Fusarium crown rot populations in spring wheat residues using quantitative real-time polymerase chain reaction. Phytopathology 100:49-57.

Ingram, D. M., and Cook, R. J. 1990. Pathogenicity of four Pythium species to wheat, barley, peas and lentils. Plant Pathol. 39:110-117.

LéVesque, C. A., and De Cock, W. A. M. 2004. Molecular phylogeny and taxonomy of the genus Pythium. Mycol. Res. 108:1363-1383.

Lucas, P., Smiley, R. W., and Collins, H. E. 1993. Decline of Rhizoctonia root rot on wheat in soils infested with Rhizoctonia solani AG-8. Phytopathology 83: 260-265.

Machado, S. 2011. Soil organic carbon dynamics in the Pendleton long-term experiments: Implications for biofuel production in Pacific Northwest. Agron. J. 103:253-260.

Machado, S., Petrie, S., Rhinhart, K., and Qu, A. 2007. Long-term continuous cropping in the Pacific Northwest: Tillage and fertilizer effects on winter wheat, spring wheat, and spring barley. Soil Tillage Res. 94:473-481.

Machado, S., Petrie, S., Rhinhart, K., and Ramig, R. E. 2008. Tillage effects on water use and grain yield of winter wheat and green pea in rotation. Agron. J. 100:154-162.

McKay, A., Roget, D., Hannam, R., and Ophel Keller, K., eds. 2008. Root Disease Risk Management Resource Manual. South Australian Research and Development Institute, Glen Osmond, South Australia.

Mitchell, C. C., Westerman, R. L., Brown, J. R., and Peck, T. R. 1991. Overview of long-term agronomic research. Agron. J. 83:24-29.

Moore, K. J., and Cook, R. J. 1984. Increased take-all of wheat with direct drilling in the Pacific Northwest. Phytopathology 74:1044-1049.

Murray, T. D. 2010. Eyespot (strawbreaker foot rot). Pages 32-34 in: Compendium of Wheat Diseases and Pests, 3rd ed. W. W. Bockus, R. L. Bowden, R. M. Hunger, W. L. Morrill, T. D. Murray, and R. W. Smiley, eds. American Phytopathological Society, St. Paul, MN.

Okubara, P. A., Schroeder, K. L., Abatzoglou, J. T., and Paulitz, T. C. 2014. Agroecological factors correlated to soil DNA concentrations of Rhizoctonia in dryland wheat production zones of Washington State, USA. Phytopathology 104:683-691.

Okubara, P. A., Schroeder, K. L., and Paulitz, T. C. 2008. Identification and quantification of Rhizoctonia solani and $R$. oryzae using real-time polymerase chain reaction. Phytopathology 98:837-847.

Ophel-Keller, K., Hartley, D., McKay, A., Herdina, and Curran, J. 2008. Development of a routine DNA-based testing service for soilborne diseases in Australia. Australas. Plant Pathol. 37:243-253.

Paulitz, T. C., and Adams, K. 2003. Composition and distribution of Pythium communities in wheat fields in eastern Washington State. Phytopathology 93: 867-873.

Paulitz, T. C., Schroeder, K. L., and Schillinger, W. F. 2010. Soilborne pathogens of cereals in an irrigated cropping system: Effects of tillage, residue management, and crop rotation. Plant Dis. 94:61-68.

Paulitz, T. C., Smiley, R. W., and Cook, R. J. 2002. Insights into the prevalence and management of soilborne cereal pathogens under direct seeding in the Pacific Northwest, U.S.A. Can. J. Plant Pathol. 24:416-428.

Pikul, J. L., Jr., and Allmaras, R. R. 1986. Physical and chemical properties of a haploxeroll after fifty years of residue management. Soil Sci. Soc. Am. J. 50: 214-219.

Poole, G. J., Harries, M., Huberli, D., Miyan, S., MacLeod, W. J., Lawes, R., and McKay, A. 2015. Predicting cereal root disease in Western Australia using soil DNA and environmental parameters. Phytopathology 105:1069-1079.

Poole, G. J., Smiley, R. W., Walker, C., Huggins, D., Rupp, R., Abatzoglou, J., Garland-Campbell, K., and Paulitz, T. C. 2013. Effect of climate on the 
distribution of Fusarium spp. causing crown rot of wheat in the Pacific Northwest of the United States. Phytopathology 103:1130-1140.

Rasmussen, P. E., and Collins, H. C. 1991. Long-term impacts of tillage, fertilizer, and crop residue on soil organic matter in temperate semiarid regions. Adv. Agron. 45:93-134.

Rasmussen, P. E., and Rohde, C. R. 1988. Long-term tillage and nitrogen fertilization effects on organic nitrogen and carbon in a semiarid soil. Soil Sci. Soc. Am. J. 52:1114-1117.

Rasmussen, P. E., and Rohde, C. R. 1989. Soil acidification from ammoniumnitrogen fertilization in moldboard plow and stubble-mulch wheat-fallow tillage. Soil Sci. Soc. Am. J. 53:119-122.

Rasmussen, P. E., and Smiley, R. W. 1994. Long-term management effects on soil productivity and crop yield in semi-arid regions of eastern Oregon. Oregon Agric. Exp. Stn. Bull. 675. Oregon State University, Corvallis.

Rasmussen, P. E., and Smiley, R. W. 1996. Soil carbon and nitrogen change in long-term agricultural experiments at Pendleton, Oregon. Pages 353-360 in: Soil Organic Matter in Temperate Agroecosystems. E. A. Paul, K. Paustian, E. T. Elliot, and C. V. Cole, eds. CRC Press, Boca Raton, FL.

Roberts, F. A., and Sivasithamparam, K. 1987. Effect of interaction of Rhizoctonia spp. with other fungi from cereal bare patches on root rot of wheat. Trans. Br. Mycol. Soc. 89:256-259.

Rovira, A. D. 1986. Influence of crop rotation and tillage on Rhizoctonia bare patch of wheat. Phytopathology 76:669-673.

Schroeder, K. L., Okubara, P. A., Tambong, J. T., Lévesque, C. A., and Paulitz, T. A. 2006. Identification and quantification of pathogenic Pythium spp. from soils in eastern Washington using real-time polymerase chain reaction. Phytopathology 96:637-647.

Schroeder, K. L., and Paulitz, T. C. 2006. Root diseases of wheat and barley during the transition from conventional tillage to direct seeding. Plant Dis. 90: 1247-1253.

Shipton, P. J. 1975. Take-all decline during cereal monoculture. Pages 137-144 in: Biology and Control of Soilborne Pathogens. G. W. Bruehl, ed. American Phytopathological Society, St. Paul, MN.

Simpfendorfer, S., McMullen, G., and Brill, R. 2012. Interaction of crown rot with root-lesion nematodes. Page 34 in: Proc. First Int. Crown Rot Workshop, Narrabri, New South Wales, Australia. R. I. S. Brettell and J. M. Nicol, eds. Grains Research and Development Corp., Canberra, Australia.

Smiley, R. W. 2009a. Water and temperature parameters associated with winter wheat diseases caused by soilborne pathogens. Plant Dis. 93:73-80.

Smiley, R. W. 2009b. Root-lesion nematodes reduce yield of intolerant wheat and barley. Agron. J. 101:1322-1335.

Smiley, R. W., Backhouse, D., Lucas, P., and Paulitz, T. E. 2009. Diseases which challenge global wheat production - root, crown, and culm rots. Pages 125-153 in: Wheat Science and Trade. B. F. Carver, ed. Wiley-Blackwell, Ames, IA.

Smiley, R. W., Collins, H. P., and Rasmussen, P. E. 1996a. Diseases of wheat in long-term agronomic experiments at Pendleton, Oregon. Plant Dis. 80:813-820.

Smiley, R. W., Gourlie, J. A., Yan, G. P., and Rhinhart, K. E. L. 2014a. Resistance and tolerance of landrace wheat in fields infested with Pratylenchus neglectus and P. thornei. Plant Dis. 98:797-805.

Smiley, R. W., and Machado, S. 2009. Pratylenchus neglectus reduces yield of winter wheat in dryland cropping systems. Plant Dis. 93:263-271.
Smiley, R. W., Machado, S., Gourlie, J. A., Pritchett, L. C., Yan, G. P., and Jacobsen, E. E. 2013a. Effects of crop rotations and tillage on Pratylenchus spp. in the semiarid Pacific Northwest United States. Plant Dis. 97:537-546.

Smiley, R. W., Machado, S., Gourlie, J. A., Pritchett, L. C., Yan, G. P., and Jacobsen, E. E. 2013b. Influence of semiarid cropping systems on root diseases and inoculum density of soilborne pathogens. Plant Dis. 97:547-555.

Smiley, R. W., Merrifield, K., Patterson, L.-M., Whittaker, R. G., Gourlie, J. A., and Easley, S. A. 2004. Nematodes in dryland field crops in the semiarid Pacific Northwest USA. J. Nematol. 36:54-68.

Smiley, R. W., and Nicol, J. M. 2009. Nematodes which challenge global wheat production. Pages 171-187 in: Wheat Science and Trade. B. F. Carver, ed. Wiley-Blackwell, Ames, IA.

Smiley, R. W., and Patterson, L.-M. 1996. Pathogenic fungi associated with Fusarium foot rot of winter wheat in the semiarid Pacific Northwest. Plant Dis. 80:944-949.

Smiley, R. W., Patterson, L.-M., and Shelton, C. W. 1996b. Fungicide seed treatments influence emergence of winter wheat in cold soil. J. Prod. Agric. 9:559-563.

Smiley, R. W., Sheedy, J. G., and Easley, S. A. 2008. Vertical distribution of Pratylenchus spp. in silt loam soil and Pacific Northwest dryland crops. Plant Dis. 92:1662-1668.

Smiley, R. W., Whittaker, R. G., Gourlie, J. A., and Easley, S. A. 2005a. Pratylenchus thornei associated with reduced wheat yield in Oregon. J. Nematol. 37:45-54.

Smiley, R. W., Whittaker, R. G., Gourlie, J. A., and Easley, S. A. 2005b. Suppression of wheat growth and yield by Pratylenchus neglectus in the Pacific Northwest. Plant Dis. 89:958-968.

Smiley, R. W., Yan, G. P., and Gourlie, J. A. 2014b. Selected Pacific Northwest crops as hosts of Pratylenchus neglectus and P. thornei. Plant Dis. 98:1341-1348.

Summerell, B. A., Burgess, L. W., and Klein, T. A. 1989. The impact of stubble management practices on the incidence of crown rot of wheat. Aust. J. Exp. Agric. 29:91-98.

Thompson, A. L., Smiley, R. W., and Garland-Campbell, K. 2015. Registration of the LouAu (Louise/IWA8608077) wheat recombinant inbred line mapping population. J. Plant Regist. 9:424-429.

Thompson, J. P., Owen, K. J., Stirling, G. R., and Bell, M. J. 2008. Root-lesion nematodes (Pratylenchus thornei and $P$. neglectus): A review of recent progress in managing a significant pest of grain crops in northern Australia. Australas. Plant Pathol. 37:235-242.

Vanstone, V. A., Hollaway, G. J., and Stirling, G. R. 2008. Managing nematode pests in the southern and western regions of the Australian cereal industry: Continuing progress in a challenging environment. Australas. Plant Pathol. 37:220-234.

Yan, G. P., Smiley, R. W., and Okubara, P. A. 2012. Detection and quantification of Pratylenchus thornei in DNA extracted from soil using real-time PCR. Phytopathology 102:14-22.

Yan, G. P., Smiley, R. W., Okubara, P. A., Skantar, A. M., and Reardon, C. L. 2013. Developing a real-time PCR assay for detection and quantification of Pratylenchus neglectus in soil. Plant Dis. 979:757-764.

Yarham, D. J. 1981. Practical aspects of epidemiology and control. Pages 353-384 in: Biology and Control of Take-all. M. J. C. Asher and P. J. Shipton, eds. Academic Press, London. 